\title{
Seabed methane emissions and the habitat of frenulate tubeworms on the Captain Arutyunov mud volcano (Gulf of Cadiz)
}

\author{
S. Sommer*, P. Linke, O. Pfannkuche, T. Schleicher, J. Schneider v. Deimling, \\ A. Reitz, M. Haeckel, S. Flögel, C. Hensen
}

Leibniz Institute of Marine Sciences, IFM-GEOMAR, Wischhofstrasse 1-3, 24148 Kiel, Germany

\begin{abstract}
Submarine mud volcanism represents an important pathway for methane from deeper reservoirs to the surface, where it enters the benthic carbon cycle. To quantify overall methane release from the Captain Arutyunov mud volcano (CAMV) and to assess the contribution of macrobenthic seep organisms to the regulation of the benthic methane flux, we linked water column methane concentrations, seabed methane emission and pore water geochemistry to the spatial distribution of seep biota. Prominent organisms of the CAMV seep biota were 3 different species of frenulate tubeworms. Seabed methane emission ranged from 0.001 to $0.66 \mathrm{mmol} \mathrm{m}^{-2} \mathrm{~d}^{-1}$. Dense patches of tubeworms were associated with the lowest seabed methane emission. Elevated methane emission was associated with a sporadic distribution of tubeworms and the occurrence of numerous mud clasts. Despite the presence of a large subsurface methane reservoir, the estimated total methane

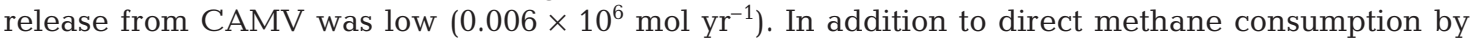
Siboglinum poseidoni, the tubeworms likely contribute to the retention of methane carbon in the sediment by affecting bacterial communities in the proximity of the tubes. The siboglinids create new meso-scale habitats on the sediment surface, increasing habitat heterogeneity and introducing niches for bacterial communities.
\end{abstract}

KEY WORDS: Mud volcano $\cdot$ Methane emission $\cdot$ Frenulate tubeworms $\cdot$ Habitat mapping

\section{INTRODUCTION}

The estimated number of known and inferred submarine mud volcanoes is in the range $10^{3}$ to $10^{5}$ (Milkov 2000, Milkov et al. 2003). In the Gulf of Cadiz mud volcanism is a prominent feature, extending from the Iberian-Moroccan shelf to the deeper regions. In addition to the mud flow activity of mud volcanoes, pockmark-like structures on the continental shelf break and authigenic carbonate crusts were reported to be related to intense hydrocarbon seepage (Gardner 2001, Pinheiro et al. 2003, Somoza et al. 2003, León et al. 2006, Hensen et al. 2007), release of free gas (Sauter et al. 2006) and the presence of gas hydrates (Milkov 2000, Pinheiro et al. 2003, Judd \& Hovland 2007, and references therein). Hence, submarine mud volcanoes are considered to represent an important, yet hardly quantified carbon source to the benthic boundary layer and the hydrosphere.

Microbial methanotrophy was early recognized as an important control mechanism for methane flux in sedimentary environments dominated by slow pore water fluid flow and diffusion as well as in freshwater systems and soils (cf. Reeburgh 2007, and references therein). In recent years the anaerobic oxidation of methane (AOM) has been identified as the major pathway of methane consumption for a wide range of cold seep ecosystems (cf. Judd \& Hovland 2007) releasing bicarbonate and sulfide into the pore water. Elevated fluxes of methane and sulfide support unique chemosynthetic seep communities (Levin 2005 and references therein), which were also observed to constitute major faunal elements in submarine mud volcano ecosystems e.g. at the Costa Rica margin, at the Håkon Mosby mud vol- 
cano in the Barents Sea and seaward of the Barbados accretionary prism (Olu et al 1997, Pimenov et al. 1999, Smirnov 2000, Gebruk et al. 2003, Linke et al. 2005, Jerosch et al. 2007). The presence of chemosynthetic communities with particular dominance of tubeworms of the genera Siboglinum, Polybrachia and Oligobrachia and also species of the bivalve mollusks Acharax and Lucinoma have been reported in mud volcanoes in the Gulf of Cadiz (Pinheiro et al. 2003, Cunha et al. 2005, Rodrigues \& Cunha 2005). However, apart from these observations, there is a lack of studies classifying distinct seep habitats at mud volcanoes in the Gulf of Cadiz in relation to their geochemical environment and seabed methane emission.

There are few studies to date on the emission of methane into the water column at cold seeps. Available estimates are based on different methodological approaches (cf. Wallmann et al. 2006). In situ measurements of the emission of dissolved methane are confined to a few prominent regions, such as the Hydrate Ridge off Oregon (Torres et al. 2002, Sommer et al.
2006) or mud volcanoes at the Costa Rica margin (Linke et al. 2005). As cold seep ecosystems are very diverse even on meter scales and below, benthic chamber flux determinations represent spatially confined site-specific spot measurements for distinct chemosynthetic habitats and no attempt has been made to extrapolate these fluxes for wider areas. Jerosch et al. (2007) provided detailed maps of different habitats and lithologies of the Håkon Mosby mud volcano but the different provinces were not related to sediment geochemistry and fluxes. To estimate the seabed methane emission from an entire mud mound off Costa Rica, Mau et al. (2006) related video-based mapping of chemosynthetic habitats with release rates of methane that were published for similar habitats but at different geographical regions.

In the present study we, firstly, aimed to estimate the overall emission of dissolved methane from the Captain Arutyunov mud volcano (CAMV) by relating distribution patterns of distinct benthic habitats with in situ measurements of methane fluxes taken with ben-

- siboglinids (area-wide)
siboglinids (patches)
* gastropods >3 indiv.
* gastropods 1-3 indiv.
shell debris
- bacterial mat
× clasts
- cast (grey)
- groove
" footprint/weight lander
- stations

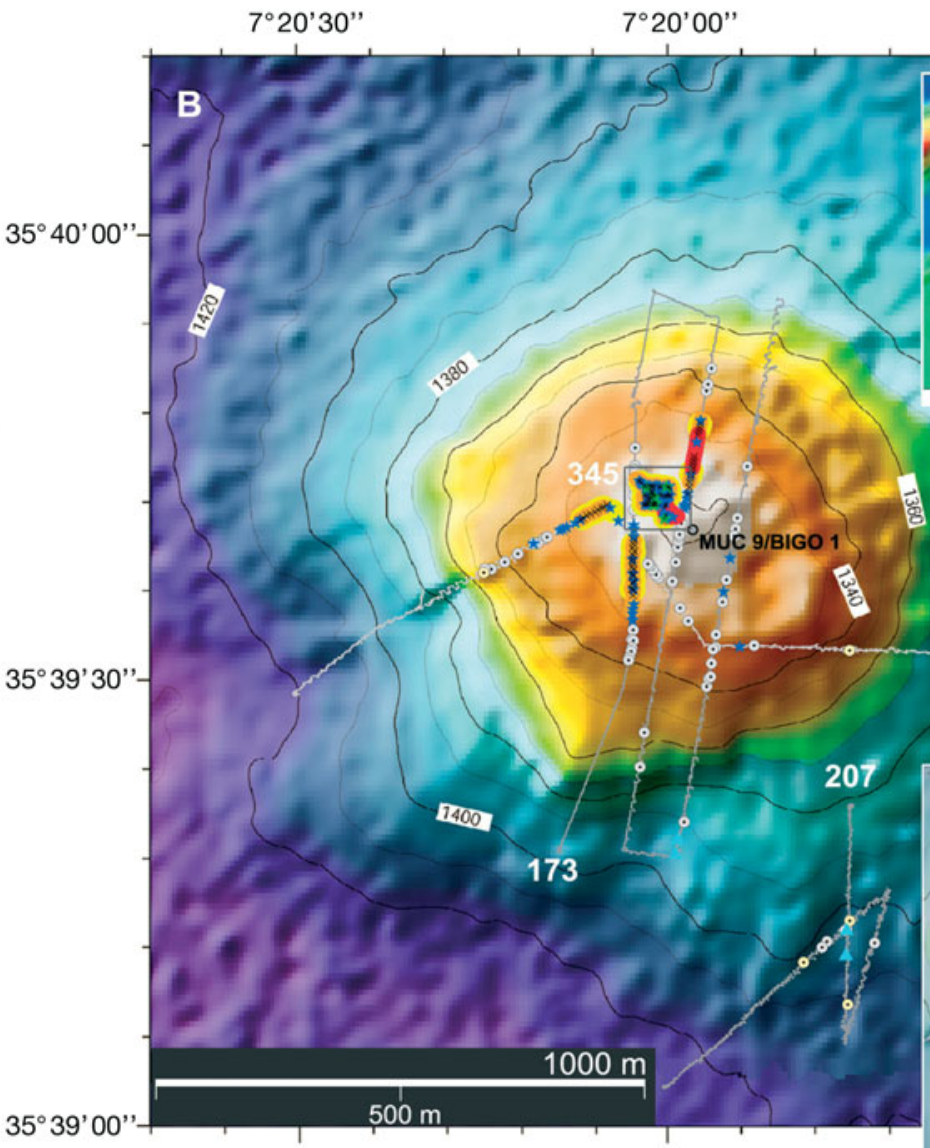

$35^{\circ} 39^{\prime} 00^{\prime}$

$7^{\circ} 19^{\prime} 30^{\prime \prime}$
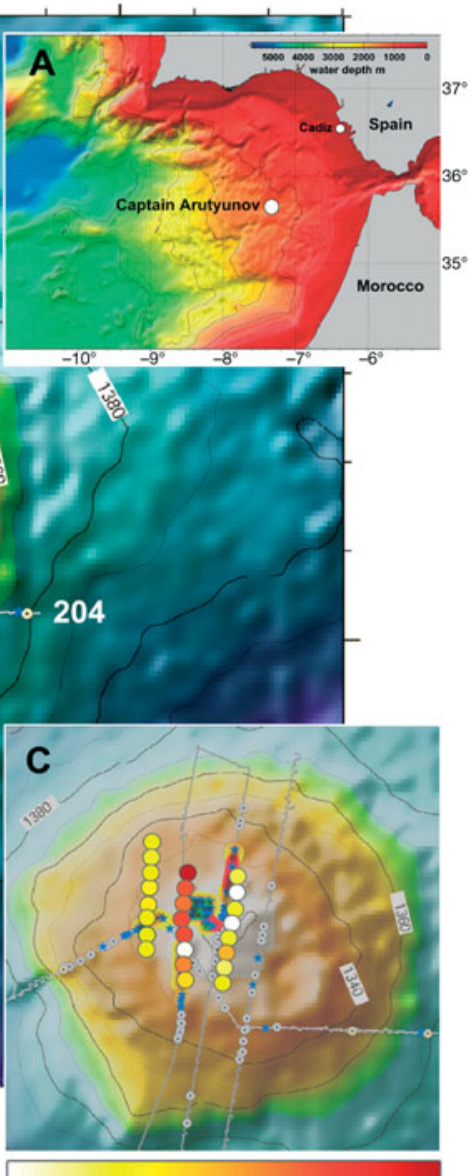

Fig. 1. (A) Captain Arutyunov mud volcano (CAMV) in the Gulf of Cadiz; (B) bathymetry of the CAMV with distribution patterns of major faunal groups and lithological features resolved during video tracks 173, 204, 207, and 345; (C) methane concentration measured $\sim 5 \mathrm{~m}$ above the sea floor, indicated by color-grade dots overlying the bathymetric map. Rectangle in (B) represents the area shown in Fig. 2

0 methane concentration $5 \mathrm{~m}$ above sea floor 
thic flux chambers. Secondly, to further understand the functional role of metazoan seep organisms and their contribution to the regulation of seabed methane emission, we attempt to bring together their distribution patterns, methane fluxes and pore water geochemistry.

\section{MATERIALS AND METHODS}

Study area and sediment sampling. During cruise $1 / 3$ of the RV 'MS Merian' in 2006 (MSM 1/3), we conducted in situ flux measurements of methane at the CAMV at about $1320 \mathrm{~m}$ depth in the central Gulf of Cadiz (Figs. 1 \& 2; Table 1). Mud volcanism in this area seems to occur largely under tectonic activity with seepage structures preferentially located along major strike slip faults or at the intersection of these faults (Pinheiro et al. 2003). The elevation of the conical shaped CAMV above the surrounding sea floor amounts to about $100 \mathrm{~m}$. The fluids originate from clay mineral dehydration at a sediment depth of about $5000 \mathrm{~m}$ (Hensen et al. 2007). However these fluids also carry a clear signal of halite dissolution (Hensen et al. 2007). The halite seems to be part of the allochthonous masses that migrate downslope from the Iberian and Morroccan continental margins towards the Atlantic Ocean (Maestro et al. 2003). The stable carbon isotope ratio of the ascending methane gas indicates its origin to be a mixture of microbial and thermogenic sources (-48.3\% VPDB, Hensen et al. 2007). The sediments

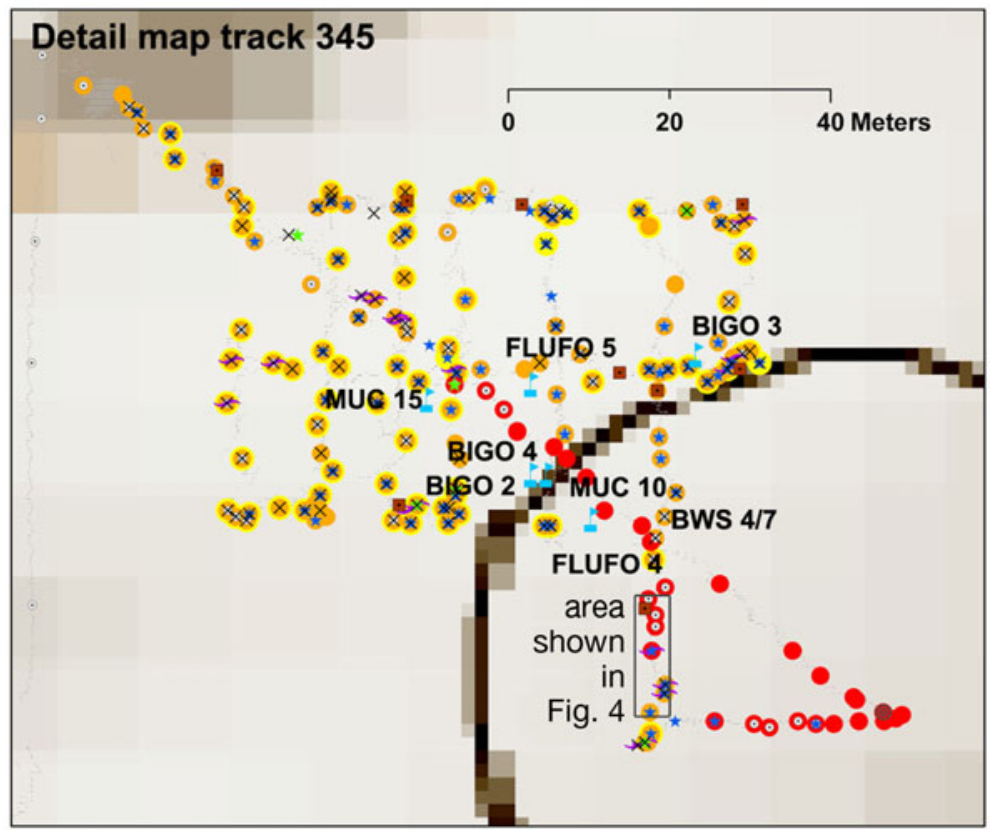

Fig. 2 Spatial distribution of major faunal groups and lithological features resolved during video track 345. See Fig. 1 for key to symbols. Grey outlined rectangle represents the area shown in Fig. 4 are generally composed of unstructured grey to greybrown clay interspersed with mud clasts of various sizes. Partly, degassing structures have been observed that result from gas hydrate dissociation.

Sediment sampling was conducted using benthic observatories and a TV-guided multiple corer (MUC). The MUC retrieved up to eight $10 \mathrm{~cm}$ diameter sediment cores of a maximal length of about $35 \mathrm{~cm}$. Upon recovery these cores were immediately transferred to a coolroom for further processing.

Benthic observatories. In situ flux measurements were conducted using the Biogeochemical Observatory (BIGO) and the Fluid Flux Observatory (FLUFO) as described in detail by Sommer et al. (2006) and Sommer et al. (2008). Each observatory contained 2 circular chambers (internal $\varnothing 28.8 \mathrm{~cm}$; area $651.4 \mathrm{~cm}^{2}$ ), herein referred to as EX and CO in BIGO, and FLUX and BU in FLUFO. A TV-guided launching system allowed smooth placement of the observatories at selected sites on the sea floor. Two to $3 \mathrm{~h}$ after the observatories were placed on the sea floor the chambers were slowly driven into the sediment $\left(\sim 30 \mathrm{~cm} \mathrm{~h}^{-1}\right)$. The water volume enclosed by the benthic chambers was in the range of 10.1 to $19.5 \mathrm{l}$, depending on penetration depth of the chamber. To trace seabed methane emission during each deployment, 8 sequential water samples $(\sim 47 \mathrm{ml})$ were taken from each of the EX, FLUX and BU chambers by means of glass syringe water samplers. From chamber CO, 16 water samples were taken. Chamber measurements were conducted for different time periods in the range of 39.1 to $66 \mathrm{~h}$ as defined from the time interval between the first and the last water sample (Table 1). During the four deployments of BIGO (BIGO 1,2,3,4), the ambient water body was monitored employing an extra syringe water sampler (8 samples).

The EX chamber was equipped with a gas exchange system to keep the oxygen concentration constant. The technical design of this gas exchange device and results of second and third deployments of EX (BIGO 2EX and BIGO 3EX) have been described by Sommer et al. (2008). The CO chamber was flushed with ambient seawater at the beginning of the incubation and subsequently at different time intervals (cf. Fig. 6) to detect temporal variability of methane emission. The operation of the FLUX and BU chambers was similar to $\mathrm{CO}$, except that the chamber water was not replaced and only 8 water samples were taken during the incubation. All methane emission measurements were conducted under oxic conditions. The oxygen concentration in all chambers did not fall below 
Table 1. Benthic stations investigated at Captain Arutyunov mud volcano during a cruise of the RV 'Merian' (MSM 1/3). Tinc. denotes the incubation time of chamber measurements. $\mathrm{CH}_{4}$ emission expressed in $\mathrm{mmol} \mathrm{m}^{-2} \mathrm{~d}^{-1}$. For the classification of the habitat see 'Results; Seafloor observation'. MUC 10 and BIGO 1CO where siboglinids were absent but numerous clasts were visible on the sediment surface were classified as clast habitat. BIGO: Biogeochemical Observatory; FLUFO: Fluid Flux Observatory, BWS: bottom water sampler; MUC: multiple corer; nd: not determined

\begin{tabular}{|c|c|c|c|c|c|c|}
\hline Station & Date (2006) & Position & Depth (m) & $\mathrm{T}_{\text {inc. }}(\mathrm{h})$ & $\mathrm{CH}_{4}$ emission & Habitat \\
\hline BIGO $1 \mathrm{CO}$ & 27 Apr & $\begin{array}{l}35^{\circ} 39.673^{\prime} \mathrm{N} \\
07^{\circ} 19.974^{\prime} \mathrm{W}\end{array}$ & 1317 & 63.3 & 0.450 & Clast \\
\hline BIGO 1EX & 27 Apr & $\begin{array}{l}35^{\circ} 39.673^{\prime} \mathrm{N} \\
07^{\circ} 19.974^{\prime} \mathrm{W}\end{array}$ & 1317 & 64.2 & 0.080 & Clast \\
\hline BIGO 2EX & 1 May & $\begin{array}{l}35^{\circ} 39.701^{\prime} \mathrm{N} \\
07^{\circ} 20.011^{\prime} \mathrm{W}\end{array}$ & 1320 & 56.2 & $0.200^{\mathrm{a}}$ & Clast \\
\hline BIGO 3EX & 7 May & $\begin{array}{c}35^{\circ} 39.7001^{\prime} \mathrm{N} \\
07^{\circ} 20.012^{\prime} \mathrm{W}\end{array}$ & 1320 & 61.2 & $0^{\mathrm{a}}$ & Clast \\
\hline $\mathrm{BIGO} 3 \mathrm{CO}$ & 7 May & $\begin{array}{c}35^{\circ} 39.7001^{\prime} \mathrm{N} \\
07^{\circ} 20.012^{\prime} \mathrm{W}\end{array}$ & 1320 & 61.4 & nd & Clast \\
\hline $\mathrm{BIGO} 4 \mathrm{CO}$ & 13 May & $\begin{array}{l}35^{\circ} 39.700^{\prime} \mathrm{N} \\
07^{\circ} 20.011^{\prime} \mathrm{W}\end{array}$ & 1318 & 39.1 & 0.439 & Clast \\
\hline FLUFO 4BU & 5 May & $\begin{array}{l}35^{\circ} 39.697^{\prime} \mathrm{N} \\
07^{\circ} 20.007^{\prime} \mathrm{W}\end{array}$ & 1325 & 43.9 & 0.001 & Siboglinid \\
\hline FLUFO 5BU & 13 May & $\begin{array}{l}35^{\circ} 39.705^{\prime} \mathrm{N} \\
07^{\circ} 20.013^{\prime} \mathrm{W}\end{array}$ & 1318 & 66.0 & 0.042 & Clast \\
\hline FLUFO 5FLUX & 13 May & $\begin{array}{l}35^{\circ} 39.705^{\prime} \mathrm{N} \\
07^{\circ} 20.013^{\prime} \mathrm{W}\end{array}$ & 1318 & 66.0 & 0.661 & Clast \\
\hline BWS 4 & 5 May & $\begin{array}{l}35^{\circ} 39.702^{\prime} \mathrm{N} \\
07^{\circ} 20.012^{\prime} \mathrm{W}\end{array}$ & 1321 & - & - & nd \\
\hline BWS 7 & 10 May & $\begin{array}{l}35^{\circ} 39.700^{\prime} \mathrm{N} \\
07^{\circ} 20.015^{\prime} \mathrm{W}\end{array}$ & 1320 & - & - & nd \\
\hline MUC 9 & 28 Apr & $\begin{array}{l}35^{\circ} 39.668^{\prime} \mathrm{N} \\
07^{\circ} 19.970^{\prime} \mathrm{W}\end{array}$ & 1316 & - & - & Siboglinid \\
\hline MUC 10 & 1 May & $\begin{array}{l}35^{\circ} 39.700^{\prime} \mathrm{N} \\
07^{\circ} 20.011^{\prime} \mathrm{W}\end{array}$ & 1318 & - & - & Clast \\
\hline MUC 15 & 12 May & $\begin{array}{l}35^{\circ} 39.696^{\prime} \mathrm{N} \\
07^{\circ} 20.013^{\prime} \mathrm{W}\end{array}$ & 1322 & - & - & Siboglinid \\
\hline
\end{tabular}

$102 \mu \mathrm{M}$ (the value from the first CO deployment, BIGO $1 \mathrm{CO})$, the bottom water oxygen concentration varied between 222 to $231 \mu \mathrm{M}$ (Sommer et al. 2008).

After the in situ measurements, the incubated sediments were retrieved for onboard pore water analyses. Immediately after retrieval of the observatories, we took onboard sediment sub-samples using plastic cores with diameters of 6 and $10 \mathrm{~cm}$ for analysis of methane and pore water chemistry, respectively. The sub-samples were promptly transferred to the coolroom, which was maintained close to in situ temperature $\left(4\right.$ to $\left.8^{\circ} \mathrm{C}\right)$ for further sample processing.

A bottom water sampler (BWS) was deployed to collect 14 water samples up to $100 \mathrm{~cm}$ above the sediment surface. The design of the BWS is based on the tripod lander frame, which houses a sampling lance in its center. This lance carries 14 sampling ports whose vertical resolution can be set in $1 \mathrm{~cm}$ intervals. Sampling is conducted using glass syringe water samplers identical to those used in the observatories. During deploy- ment the BWS remained tethered to the ship. Sampling was controlled using an online video system. To avoid sampling of suspended sediment particles and gases released from the sea floor due to disturbance, water sampling was actuated about 30 to $45 \mathrm{~min}$ after placement of the BWS on the sea floor.

Methane. Methane concentrations of the water samples obtained by the BWS, as well as water and sediment samples taken by the observatories, were determined by a modified 'head space' analysis (Linke et al. 2005). Immediately after retrieval of the observatories, $10 \mathrm{ml}$ of the syringe water samples were carefully transferred into a septum-stoppered $21.6 \mathrm{ml}$ glass vial containing $3 \mathrm{~g} \mathrm{NaCl}$. The volume of the resulting head space was $10.2 \mathrm{ml}$. Methane concentrations in sediment cores were determined in $1 \mathrm{~cm}$ intervals down to a depth of $14 \mathrm{~cm}$ followed by $2 \mathrm{~cm}$ intervals. From each depth horizon, a $1.6 \mathrm{ml}$ sub-sample was transferred into a septum-stoppered glass vial containing $6 \mathrm{ml}$ of saturated $\mathrm{NaCl}$ solution and $1.5 \mathrm{~g}$ of $\mathrm{NaCl}$ in excess. 
The volume of headspace was $13.3 \mathrm{ml}$. Within $24 \mathrm{~h}$, the methane concentration in the headspace was determined using a Shimadzu GC 14A gas chromatograph fitted with a flame ionization detector and a $4 \mathrm{~m} \times$ $1 / 8$ inch Poraplot Q (mesh 50/80) packed column. Prior to the measurements the samples were equilibrated for $2 \mathrm{~h}$ on a shaking table. Precision to reproduce a methane standard of 9.98 ppm was $0.2 \%$.

Seabed methane emission in the FLUX and BU chambers was calculated from the slope of the linear regression of the methane concentrations versus time. Methane flux in the CO chamber was calculated in the same way; however only the first time period prior to the second chamber water exchange was considered (cf. Fig. 6) to be comparable to the flux measurements made in the FLUX and BU chambers. The calculation of the methane flux in the EX chamber, which was connected to a gas exchange system, has been described by Sommer et al. (2008). As all measurements were made under oxic conditions, the methane flux rates of the different chambers are assumed to be comparable, driven by naturally occurring processes, and not affected by changing redox conditions inside the chamber.

Methane concentrations in the water samples retrieved by CTD/water rosette casts were measured using the vacuum degassing method of Lammers \& Suess (1994) as modified by Rehder et al. (1999). We put $1600 \mathrm{ml}$ of water into pre-evacuated $2200 \mathrm{ml}$ glass bottles closed with valve caps to avoid air contamination. A calibrated flow meter (Engolit Flow-Control 100s DMK) was used to determine the precise volume transferred into the glass bottles. Methane concentration was determined as described above. Comparison between the head space method and the vacuum degassing method was not conducted.

Stable isotope composition of methane carbon was determined using a continuous flow GC-IRMS (Thermo Finnigan Trace GC2000/Thermo Finnigan MAT 253). For calibration, $\mathrm{CO}_{2}$ gas (-24.6\% VPDB, Air Liquide Iso Top) was used as a standard. Average precision to reproduce this standard was $0.03 \%$.

Pore water chemistry. The sediment was extruded out of the plastic liner and cut into 1 to $2 \mathrm{~cm}$ slices. Subsequently, the pore water was extracted using a lowpressure squeezer (argon at 1 to 5 bar). While being squeezed out, the pore water was filtered through $0.2 \mu \mathrm{m}$ cellulose acetate Nuclepore filters and collected in recipient vessels. Squeezing of the sediment samples might squash the siboglinids and other infaunal organisms, releasing solutes into the pore-fluid. These effects were not considered during the analyses.

Onboard, the collected pore water samples were analysed for their content of total alkalinity (TA), chloride, sulphate and sulfide. In addition, $\sim 5 \mathrm{ml}$ of wet sediment were collected and stored at about 4 to $8^{\circ} \mathrm{C}$ for the determination of porosity at the IFM-GEOMAR shore-based laboratory.

Pore water TA was determined by titration with $0.02 \mathrm{~N} \mathrm{HCl}$ using the Tashiro indicator, a mixture of methyl red and methylene blue. The titration vessel was bubbled with nitrogen to strip any $\mathrm{CO}_{2}$ and $\mathrm{H}_{2} \mathrm{~S}$ produced during the titration. The International Association for the Physical Sciences of the Oceans (IAPSO) seawater standard was used for calibration of the method with an accuracy of $0.01 \mathrm{mEq}^{-1}$.

The pore water chloride and sulfate content were determined by ion chromatography (Metrohm ion chromatograph with a conventional anion-exchange column); carbonate-bicarbonate solution was applied as an eluent. Again, the IAPSO seawater standard was used for calibration, with a relative precision of $<5 \%$. Pore water sulphide concentrations were analyzed on board using standard photometric procedures (Grasshoff et al 1983).

Sediment porosity was determined by measuring the weight before and after freeze-drying the wet sediment sample and then transforming the weight difference into a volume ratio (volume of pore water/volume of bulk sediment) assuming a dry sediment density of $2.5 \mathrm{~g} \mathrm{~cm}^{-3}$ and a seawater density of $1.024 \mathrm{~g} \mathrm{~cm}^{-3}$.

Detailed descriptions of the methods are available at http://www.ifm-geomar.de/index.php?id=1858\&L=1.

Video imaging and areal methane flux. Four video tracks were conducted (173, 204, 207, 345; Fig. 1), along which surface sediments of the CAMV were videomapped to elucidate zones with distinct lithologic features and fauna related to geochemistry and seabed methane emission (Figs. 1B \& 2). Seafloor observation was conducted with a towed ocean floor observation system (OFOS) equipped with a video and still camera. This system was towed $\sim 2 \mathrm{~m}$ above the seafloor at a velocity of about $0.5 \mathrm{~m} \mathrm{~s}^{-1}$. The aperture of the video camera was $58^{\circ}$ in horizontal direction of the image, representing $\sim 2$ m. During Tracks 173, 204, and 207, short sequences of video recordings (2 s) were taken every $30 \mathrm{~s}$. During Track 345 video recording was continuous. Using the time label of the video images in relation to the DVS ship navigation data, the video images were geo-referenced using ESRI Arc Map 9.1 with the extension Adelie-GIS: underwater vehicle data post-processing tools (IFREMER Vers. 1.8). The entire length of the video profiles was $\sim 7278 \mathrm{~m}$, covering an area of $\sim 14556 \mathrm{~m}^{2}$, analyzed by visual inspection. The video sequences, still photographs and macroscopic photographs from sediment surfaces retrieved from observatory- and MUC deployments allowed identification of typical sea floor features and fauna as well as localization and quantification of the area covered by these specific entities. The areas of the habitats were calculated using an average width of $2 \mathrm{~m}$ of the sea floor image and the distance covered by the re- 
spective habitat alongside the different tracks. Areawide seabed methane emission was calculated by multiplying these areas with the methane emission rates measured in benthic chambers presumed to be typical for these habitats.

\section{RESULTS}

\section{Seafloor observation}

The features of the areas used to identify specific habitats included areas with abundant patches or areas almost entirely populated by siboglinid tubeworms (Figs. 3A,B \& 4) and areas with numerous mud clasts on the sediment surface (Figs. 3G,H \& 4). Occurrence of shell debris (Fig. 3G) was further used to characterize the seafloor. Presence of clasts and shell debris was only noted when their coverage of the sea floor represented $>2 \%$ per image. Presence of live gastropods (Fig. 3I, arrows), corals as well as furrows (Fig. 3I) in the sea floor was recorded. Conspicuous conical shaped casts of sediments (Fig. 3L), caused by bioturbating metazoans were also included in mapping.

Presence of dense siboglinid assemblages, which on the video images can only be resolved as brownish bush-like structures, was verified by comparison with sediments retrieved during the FLUFO 4BU deployment (Fig. 3C-E) with a video image showing the location of chamber retrieval (Fig. 3B, encircled C). This photo clearly shows the brownish bush-like structures close to the footprint left by the benthic chamber. When zooming in, the tubes of the siboglinids, which also are visible at the sediment surface of the benthic chamber (Fig. 3C,D) can be detected at the edge of the footprint.

We identified 3 habitats with relevance to the quantification of sea floor methane emission: the siboglinid habitat, the clast habitat and an area dominated by conical sediment casts.

\section{Siboglinid habitat}

Sediments with extremely abundant colonies of small siboglinid tubeworms are hereafter referred to as siboglinid habitat (Figs. 3A-F \& 4). Post-cruise taxonomical investigations of the siboglinid tubeworms revealed that 3 different species (Hilario et al. 2008) of frenulate tubeworms were present at CAMV, of which a description will be published elsewhere. These comprise 2 different species belonging to the genus Siboglinum - one not further identified and the other $S$. poseidoni. The third species is assumed to be a member of the genus Polybrachia. During the cruise we could not distinguish between these species, hence we cannot re- port on either their spatial distribution or the composition of tubeworm assemblages at the different sites.

Two areas of the siboglinid habitat were found atop CAMV and at its northern flank (Figs. 1B \& 2, red dots). Sediments retrieved from MUC 9, MUC 15, and particularly FLUFO 4BU, revealed dense populations of these tubeworms with abundances of up to 17500 individuals $\mathrm{m}^{-2}$ (MUC 15). Due to time constraints, the abundance of the siboglinids was only determined for MUC 15. The anterior ends of the worms' tubes extended into the water column for 3 to $4 \mathrm{~cm}$ (Fig. 3D), creating dense 'forests' above the sediment-water interface (Fig. 3E). The view from above on the sediment surface in FLUFO 4BU revealed that these siboglinid assemblages are set off from the grey sediment as brownish tufts which cover approximately $66 \%$ of the benthic chamber area (Fig. 3C). On a spatial scale of several meters, the distribution of the siboglinid assemblages occurred either in elongated strands or in ring structures (Fig. 4). These patterns might be related to different fronts of mud flow, where younger mud flows overlie older ones. On this scale the siboglinid habitat appeared relatively homogeneous, almost without the presence of mud clasts at the sediment surface. Two individuals of the solitary coral Caryophyllia sp. were found in the chamber of FLUFO 4BU. Only a few small patches $(\mathrm{cm})$ of microbial mats were observed within an area densely populated by siboglinids (Fig. 2). Inside the grooves not populated by siboglinids, abundant live gastropods were observed (Fig. 3I). Evidence for gas hydrates buried a few centimeters beneath the sediment surface was obtained at site MUC 15.

\section{Clast habitat}

In this habitat, clasts of numerous unsorted mud stones are visible at the sediment surface, often associated with gastropods and shell debris (Figs. 3G \& 4). An example of a clast habitat enclosed in the benthic chamber of BIGO $3 \mathrm{CO}$ is shown in Fig. 3H. In the clast habitat siboglinids were present to a varying extent but not as dominant as in the siboglinid habitat. If present at all, they formed only small patches on the sediment surface; often they were only detected during processing of the sediment samples. With the resolution provided by the video and still images it was not possible to distinguish between zones of low abundance or absence of siboglinids within the clast habitat. Thus, BIGO $1 \mathrm{CO}$ and MUC 10; where no siboglinids were found but many clasts were visible on the sediment surface; were assigned to the clast habitat.

Extended clast habitats (Figs. 1B \& 2, orange dots), observed at the fringes of the siboglinid habitat, were present atop of northeastern CAMV and at the north- 

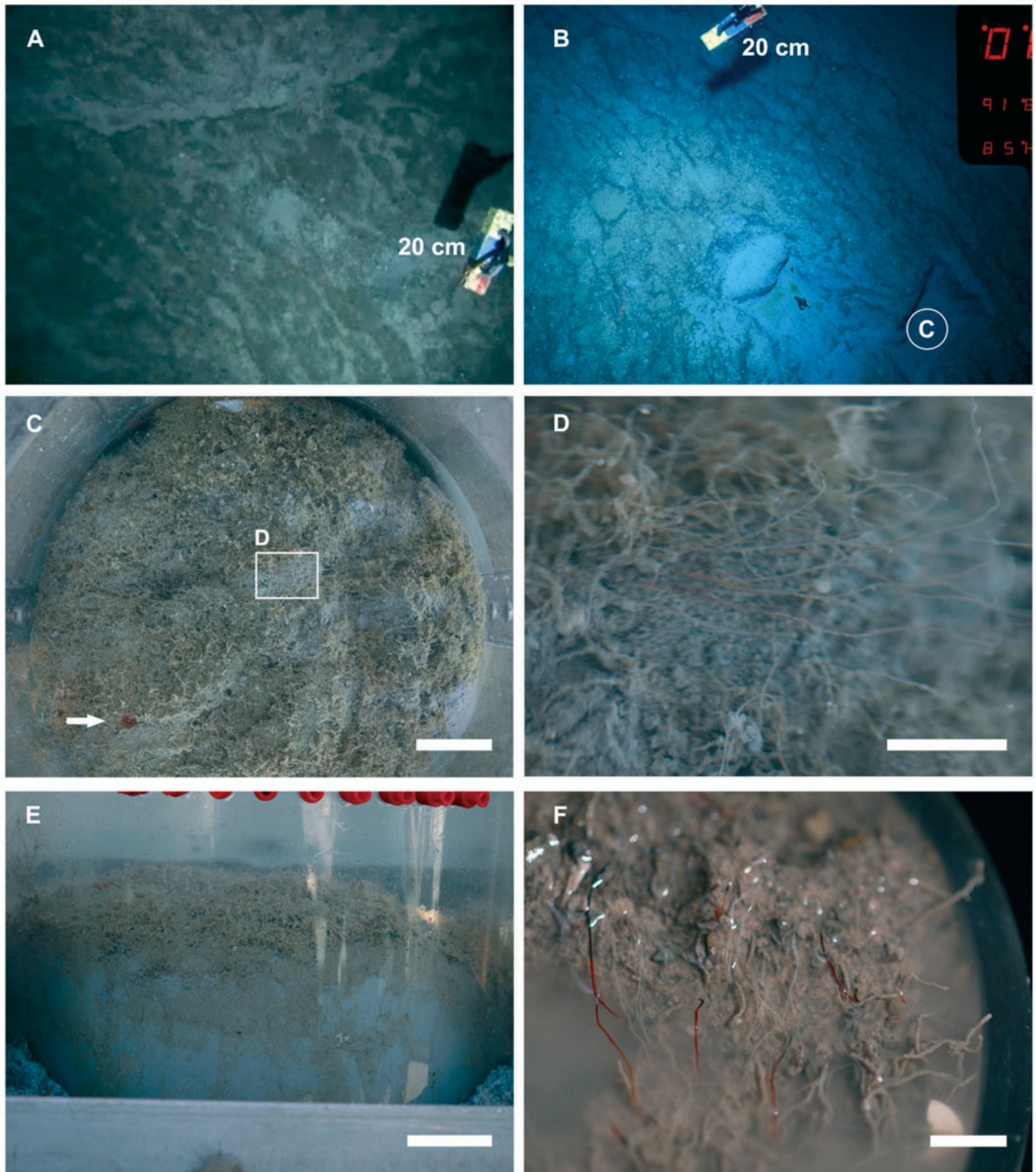

Fig. 3. Faunal groups and lithological features used to characterize distinct biota: (A) dense accumulations (olive-green spots) of siboglinid tubeworms; (B) settlement patterns of siboglinid tubeworms (olive-green spots) and foot prints of the chamber (encircled C, $\varnothing 29 \mathrm{~cm}$ ) and ballast weights left from the fourth deployment of the Fluid Flux Observatory (FLUFO 4); (C) view from the top on a sediment surface enclosed by a benthic chamber (FLUFO 4BU) with siboglinids extending their anterior end of the tubes into the water column forming dense patches (arrow: solitary coral Caryophyllia sp.); (D) close-up of the sediment surface shown in C (rectangle D), displaying filament-like tubes of the siboglinids beyond the grey sediment surface; (E) side view into the chamber shown in $\mathrm{C}$, tubes extending into the water column forming dense 'forests' above the sediment surface; (F) close-up of the surface sediment (TV-guided multiple corer deployment 15 [MUC 15]) with siboglinid tubes; (G) mud clasts and few patches of siboglinid tubeworms; $(\mathrm{H})$ view from the top into a benthic chamber displaying a sediment surface characterized by numerous clasts (Biogeochemical Observatory deployment 3, benthic chamber CO [BIGO 3CO]); (I) groove in the seafloor populated by abundant live gastropods (arrows); (J) sliding track of a lander (BIGO 4) revealing shallow gas hydrates buried only a few $\mathrm{cm}$ below the sediment surface; (K) gas cavern left from dissociating gas hydrates during retrieval of MUC 15; (L) sediment surface at the flanks of CAMV displaying conical shaped mud casts (bright grey, arrows). Scale bars: C, E, H: $5 \mathrm{~cm} ; \mathrm{D}, \mathrm{F}: 1 \mathrm{~cm} ; \mathrm{J}: 50 \mathrm{~cm}$ 

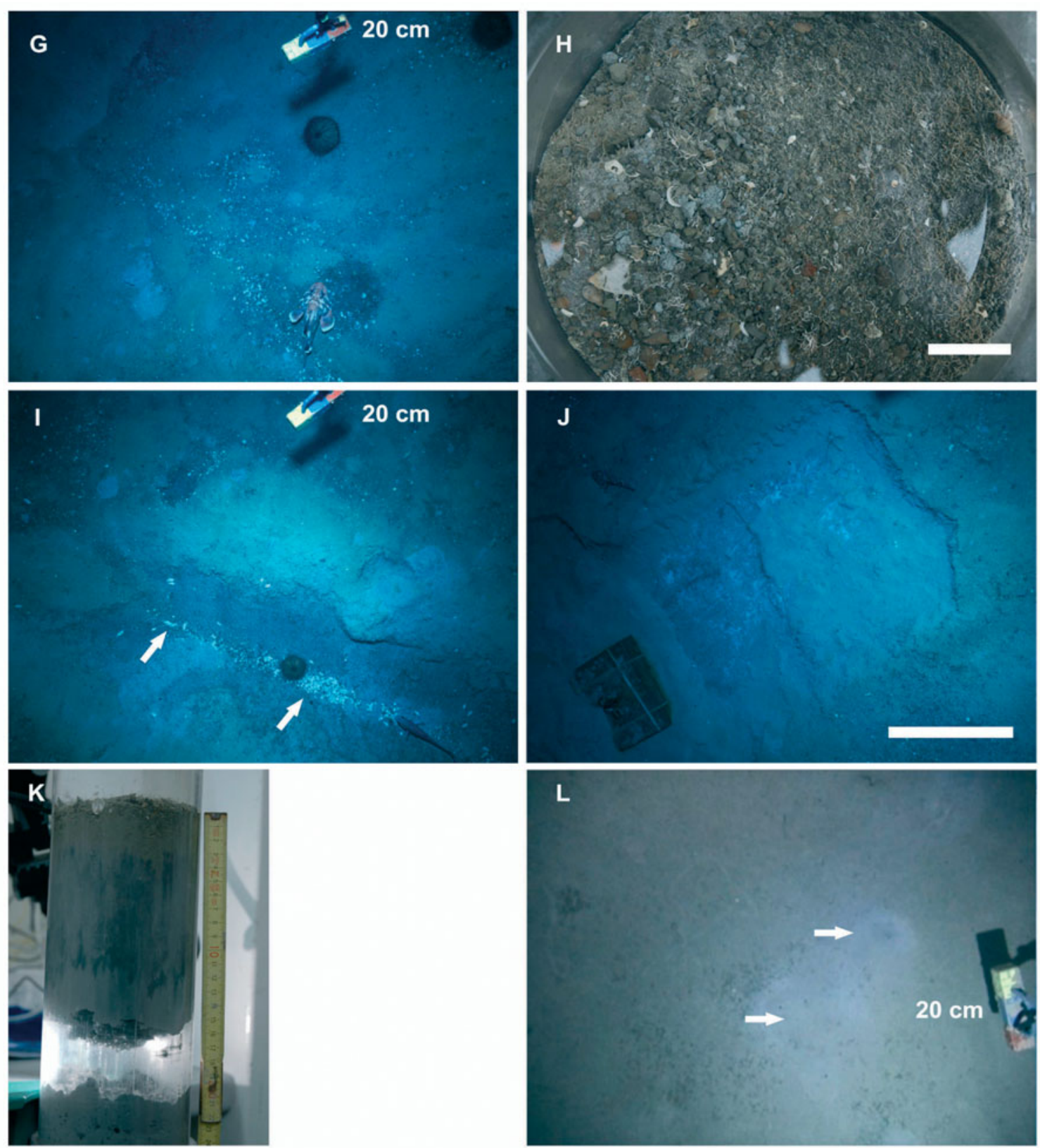

Fig. 3 (continued)

ern, southern and eastern upper flanks. In this environment, gas hydrates buried beneath a thin sediment layer $(<10 \mathrm{~cm})$ were revealed from tracks caused from a lander sliding downhill after placement on the seabed (Fig. 3J).

\section{Conical sediment casts}

In the sector covering $\sim 10^{\circ}$ to $\sim 190^{\circ}$ of the CAMV and at its flanks seabed morphology changed and no further indications of fluid/gas seepage and mud flow were found. Presence of conspicuous conical shaped sediment casts (Fig. 3L, arrows) indicated intense bioturbation. At the mid-slope of the southern flank of the mud volcano small cold-water coral colonies were observed.

\section{Methane in the water column}

Only weak emission of free gas from CAMV into the water column was detected during the hydro-acoustic survey. Methane concentrations in the bottom $\sim 5 \mathrm{~m}$ of 


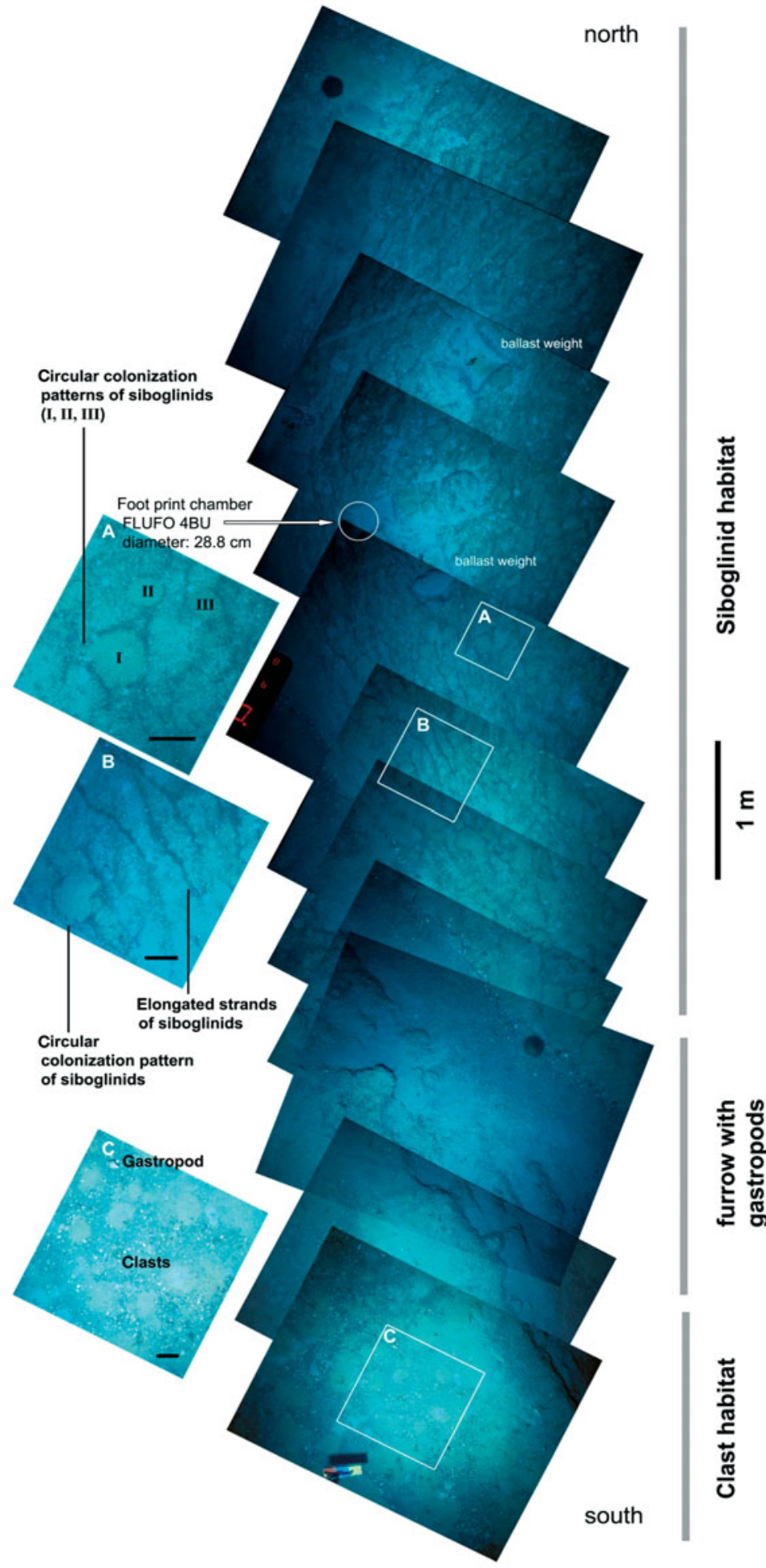

Fig. 4. Transition between the clast habitat and the siboglinid habitat separated by a groove populated by gastropods. (A, B) circular and elongated colonization patterns of siboglinids, offset from the bright sediment as darkish structures; (C) clast habitat where numerous clasts of mainly mudstones were visible on the sediment surface. Scale: $10 \mathrm{~cm}$. $1 \mathrm{~m}$ scale bar refers to the composite image. The foot print left by the chamber FLUFO 4BU (cf. Fig. 3C-E) is denoted as a white circle which is drawn to scale. Abbreviations as in Fig. 3 the water column measured along a spatial grid atop the northwestern section of the CAMV reached $\sim 8 \mathrm{nM}$, slightly higher than the background of $2 \mathrm{nM}$ (Fig. 1C).

Vertical methane profiles in the bottom water in the area with patchily distributed siboglinids and clasts (BWS 4, BWS 7) were highly variable. With increasing distance from the sea floor, methane levels decreased rapidly (Fig. 5). During BWS 7 deployment, an extremely high methane concentration ( 20000 nM) was measured, with a $\delta^{13} \mathrm{C}$ value of $-49.6 \%$. Methane carbon isotopic composition during BWS 4 showed very high $\delta^{13} \mathrm{C}$ values of up to $-4.1 \%$ close to the sediment-water interface but this value dropped to $-49 \%$ with increasing distance from the sea floor.

Bottom-water methane concentrations measured during the different lander deployments (BIGO 1, 2, 3, 4) at $\sim 30 \mathrm{~cm}$ above the sediment surface were as high as $417 \mathrm{nM}$, significantly higher than background levels. The highest methane bottom-water levels were found during deployments BIGO 2, 3 and 4, which were located in the clast habitat.

\section{Seabed methane emission}

In total, 8 benthic chamber measurements of seabed methane emission were conducted atop CAMV, with values ranging from 0 to $0.66 \mathrm{mmol} \mathrm{m}^{-2} \mathrm{~d}^{-1}$, (Table 1, Fig. 6). Seabed methane emission from the siboglinid habitat was very low (FLUFO 4BU: $0.001 \mathrm{mmol} \mathrm{m}^{-2}$ $\left.\mathrm{d}^{-1}, \mathrm{n}: 1\right)$ compared to the clast habitat (range: 0 to $0.66 \mathrm{mmol} \mathrm{m}^{-2} \mathrm{~d}^{-1} ; 0.27 \pm 0.25 \mathrm{mmol} \mathrm{m}^{-2}$ $\mathrm{d}^{-1}$ [mean $\left.\left.\pm \mathrm{SD}\right] ; \mathrm{n}: 7\right)$, including BIGO 1CO, where numerous clasts but no siboglinids were detected (Table 1, Fig. 6). Temporal variability of methane flux during the different chamber incubations was low, except for BIGO 1CO. During the BIGO $1 \mathrm{CO}$ flux measurement, the chamber water was replaced 3 times. In the first period, methane flux (0.45 mmol m $\mathrm{m}^{-2} \mathrm{~d}^{-1}$ ) was 4.5-fold higher than the methane flux $\left(0.1 \mathrm{mmol} \mathrm{m}^{-2} \mathrm{~d}^{-1}\right)$ measured after the chamber water had been replaced for the second time. Temporal variability of methane emission from another clast habitat (BIGO 4CO) during 3 time periods was low $\left(0.44 \pm 0.06 \mathrm{mmol} \mathrm{m}^{-2} \mathrm{~d}^{-1}\right)$. Due to rough sea floor topography, it was not possible to conduct methane flux measurements above the grooves densely populated by gastropods. 
The video imaging covered a seepage area of $\sim 1896 \mathrm{~m}^{2}$ atop CAMV, from which $22 \%$ was classified as siboglinid habitat and the remaining $78 \%$ as clast habitat. Presuming a methane flux of $0.001 \mathrm{mmol} \mathrm{m}^{-2} \mathrm{~d}^{-1}$ for the siboglinid habitat, methane emission from this area amounts to 0.4 mmol d $\mathrm{d}^{-1}$. Unfortunately, we were not able to conduct replicate flux measurements in the siboglinid habitat. Only after intense post-cruise image processing were we able to identify the brownish strands on the video images (Figs. 3A,B \& 4) as dense patches of siboglinids. In comparison to the siboglinid habitat, average methane emission from the clast habitat was $399 \mathrm{mmol} \mathrm{d}^{-1}$.
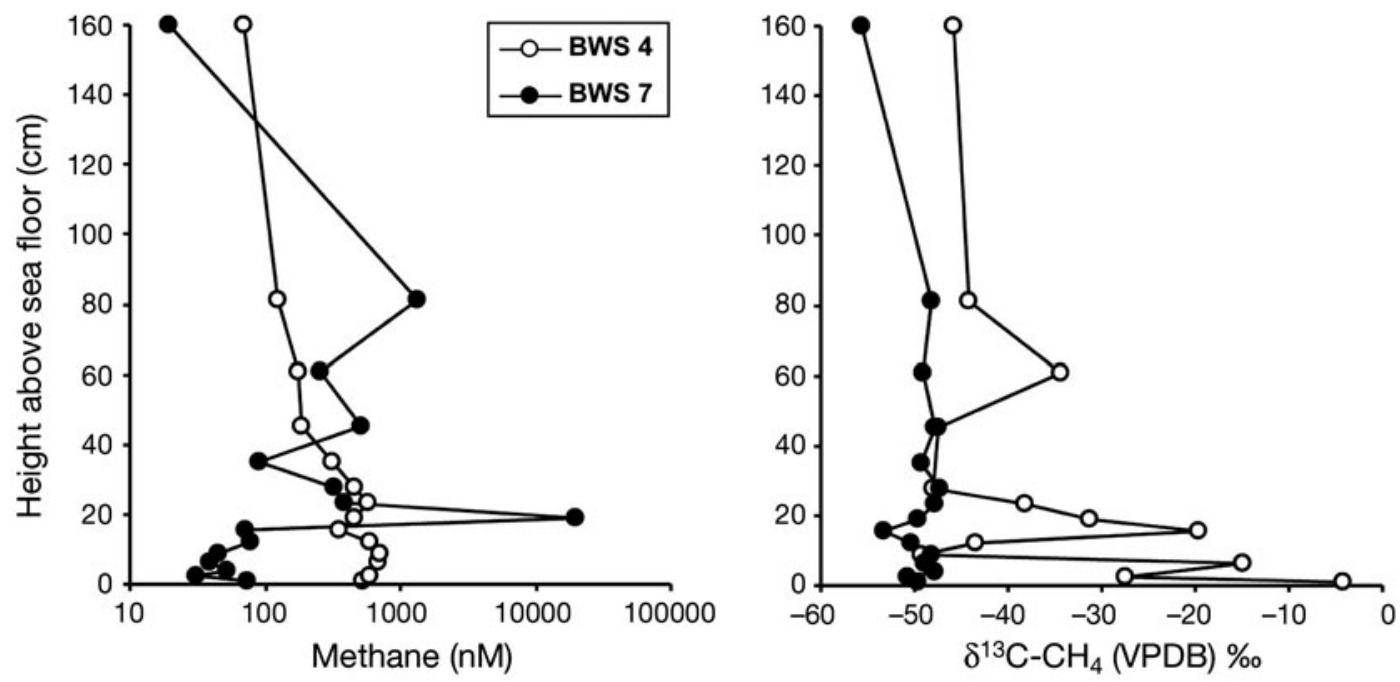

Fig. 5. Left panel: methane concentrations in the bottom water during deployment of bottom water samplers (BWS) 4 and 7 ; right panel: corresponding $\%{ }^{13} \mathrm{C}-\mathrm{CH}_{4}$ values (VPDB)
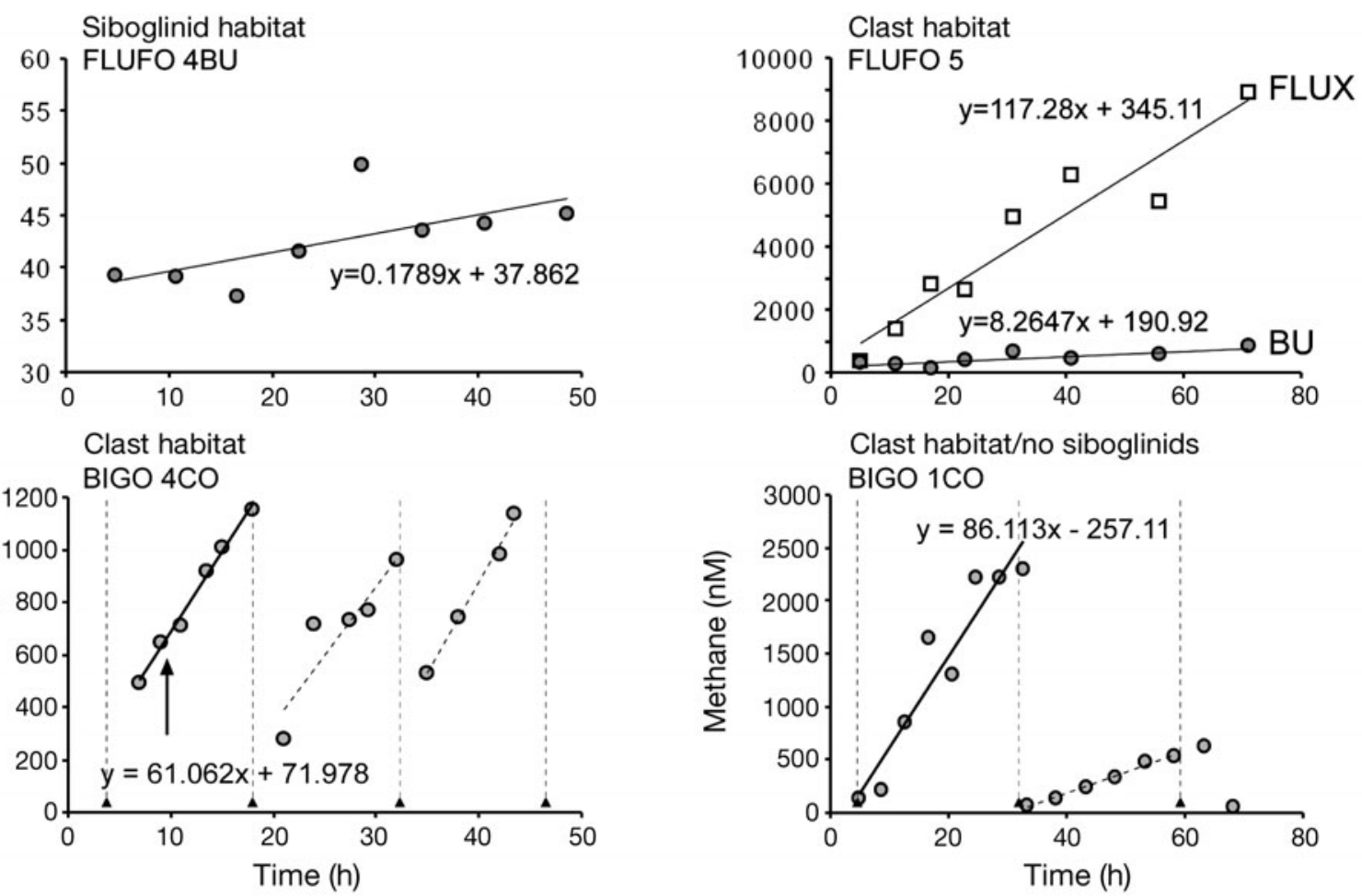

Fig. 6. Time course of methane concentration in the bottom water enclosed by benthic chambers (BU, FLUX, CO) at the siboglinid and clast habitat. In situ fluxes were calculated using the slope of the linear regressions. Filled triangles and vertical dashed lines indicate the time when the water body of the benthic chamber has been exchanged with ambient water during deployment of BIGO $1 \mathrm{CO}$ and BIGO 4CO. Abbreviations defined in 'Benthic observatories' subsection of 'Materials and methods' 


\section{Vertical distribution of siboglinid tubeworms}

We carefully prepared a sediment core containing gas hydrates retrieved from $\sim 16 \mathrm{~cm}$ below the sediment surface $\mathrm{cm}$ during deployment of MUC 15 to determine the depth distribution of siboglinids. After gently washing away the uppermost surface $(\sim 5 \mathrm{~mm})$ of the sediment, the anterior end of the tubes, whose coloration appeared translucent and milky white, became visible (Fig. 3F, view of the exposed sediment surface of the sediment core). Below the sediment surface, the middle part of the tubes appeared red. At sediment depths of 6 to $9 \mathrm{~cm}$, the lower distribution limit of the siboglinids was reached. At these depths the coloration of the posterior tubes changed again into a translucent milky white. However, tube lengths of up to $25 \mathrm{~cm}$, which likely belong to a different tubeworm species, were also reported from CAMV (O. Pfannkuche et al. unpubl.). Bivalve mollusks of the genus Thyasira, which live buried several centimeters below the sediment surface, occurred sporadically. At all sites characterized by the presence of siboglinids, except from FLUFO 4BU, numerous different-sized clasts of (mostly) mudstone occurred throughout the entire sediment column.

Scanning electron microscope (SEM) analysis of a siboglinid tube $(\varnothing \sim 100 \mu \mathrm{m})$ revealed a complex structure, where thicker, apparently mechanically more robust rings were connected to each other with thin chitin layers, forming a flexible structure (Fig. 7). It appears that flexible, thinner chitinous tissues connect thicker rings that constitute the basic structure throughout the entire length of the tube. The rings are composed of several layers of densely 'woven' chitin fibres. Given the spatial resolution used for SEM analyses we did not find any pores in the tube wall. The inside and outside of the tube were very clean and no bacteria or other organisms attached to it were discerned.

\section{Sediment geochemistry}

Methane

The occurrence of abundant siboglinid tubeworms at CAMV was related to high pore water methane concentrations of up to $5.3 \mathrm{mM}$ (Fig. 8). At these sites (MUC 9, MUC 15, FLUFO 4BU), the depth of the onset of increased pore water methane levels was between 5.5 and $7.5 \mathrm{~cm}$, and associated with the penetration depth of the siboglinid tubes. Above this transition zone, methane concentrations were $<3 \mu \mathrm{M}$. In the clast habitat areas, the methane front was located either in deeper sediment horizons and was associated with comparatively low methane concentrations (BIGO $3 \mathrm{CO}$ ), or this zone was very close to the surface and associated with high sulfide concentration of up to $1.9 \mathrm{mM}$. In clast habitats where siboglinids were absent, the methane-non-methane transition zone was located either too deep, exceeding the lower distribution limit of the tubeworms (MUC 10), or the methane concentrations in the uppermost $10 \mathrm{~cm}$ sediment layer were $<1 \mu \mathrm{M}$ (BIGO 1CO, not shown).

A detailed view of the pore water methane profiles in the uppermost $9 \mathrm{~cm}$ of the sediment shows that at the siboglinid habitat (MUC 15, FLUFO 4BU), slightly elevated methane levels at the sediment surface were measured that were not apparent in the clast habitat. MUC 9 was not included in Fig. 9, as the sediment samples for methane were taken at larger vertical increments. Methane minima generally occurred in the upper sediment at 1.5 to $2.5 \mathrm{~cm}$ depth.

Methane carbon stable isotope composition was measured for the sites FLUFO 4BU, MUC 15, MUC 9 and MUC 10 (Fig. 8). The vertical profiles from all these sites display a pronounced peak of heavier methane, indicating intense anaerobic methane oxidation. The depth of this peak is related to the zone
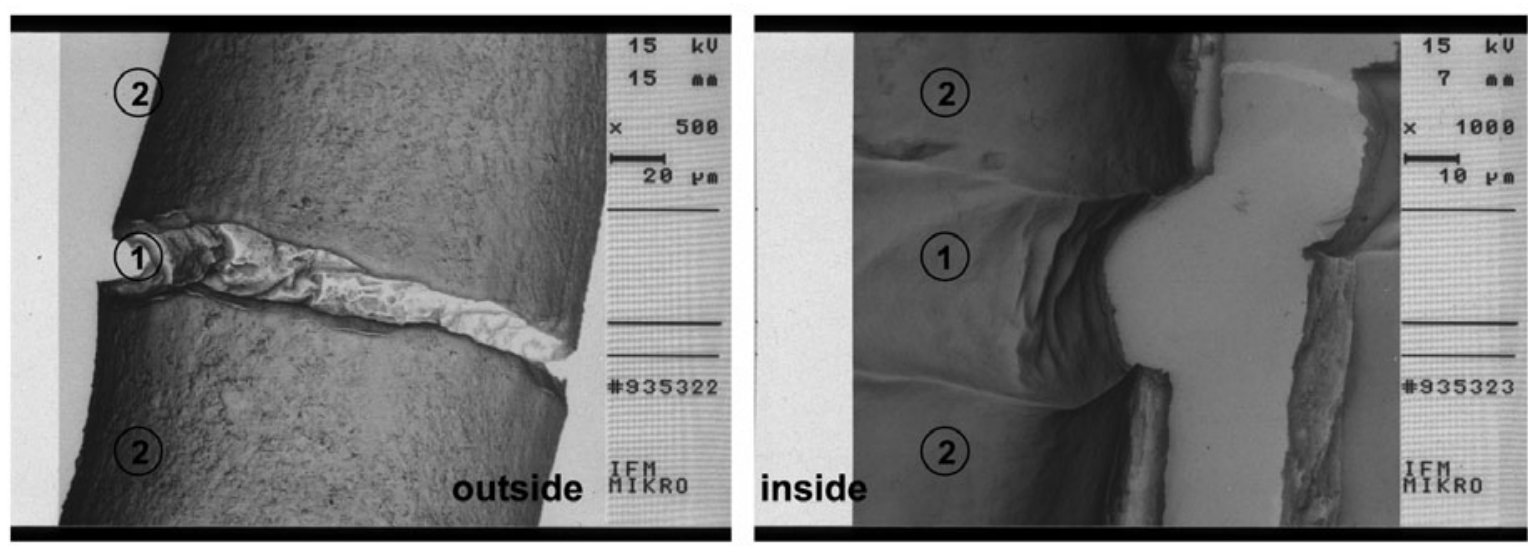

Fig. 7. Scanning electron microscope images of the outside and inside of the siboglinid tube. The spatial scale is denoted in the black bar. A sequence of multilayered thicker chitin rings (2) linked to each other with thinner chitin tissues (1) form the tube structure and likely provide mechanical flexibility 
where methane becomes almost depleted. At MUC 15, a distinct negative isotopic excursion of methane was determined just below the zone of intense methane oxidation between 11.5 and $15 \mathrm{~cm}$ depth. During recovery of MUC 15, gas hydrates, buried below $15 \mathrm{~cm}$ sediment depth, dissociated, creating a gas-filled cavern in the sediment with a volume of $\sim 353 \mathrm{~cm}^{3}$ (Fig. 3K). The $\delta^{13} \mathrm{C}$ value of free methane gas from this cavern was $-51.3 \%$. Astonishingly, the surface sediment above the cavern was not destroyed due

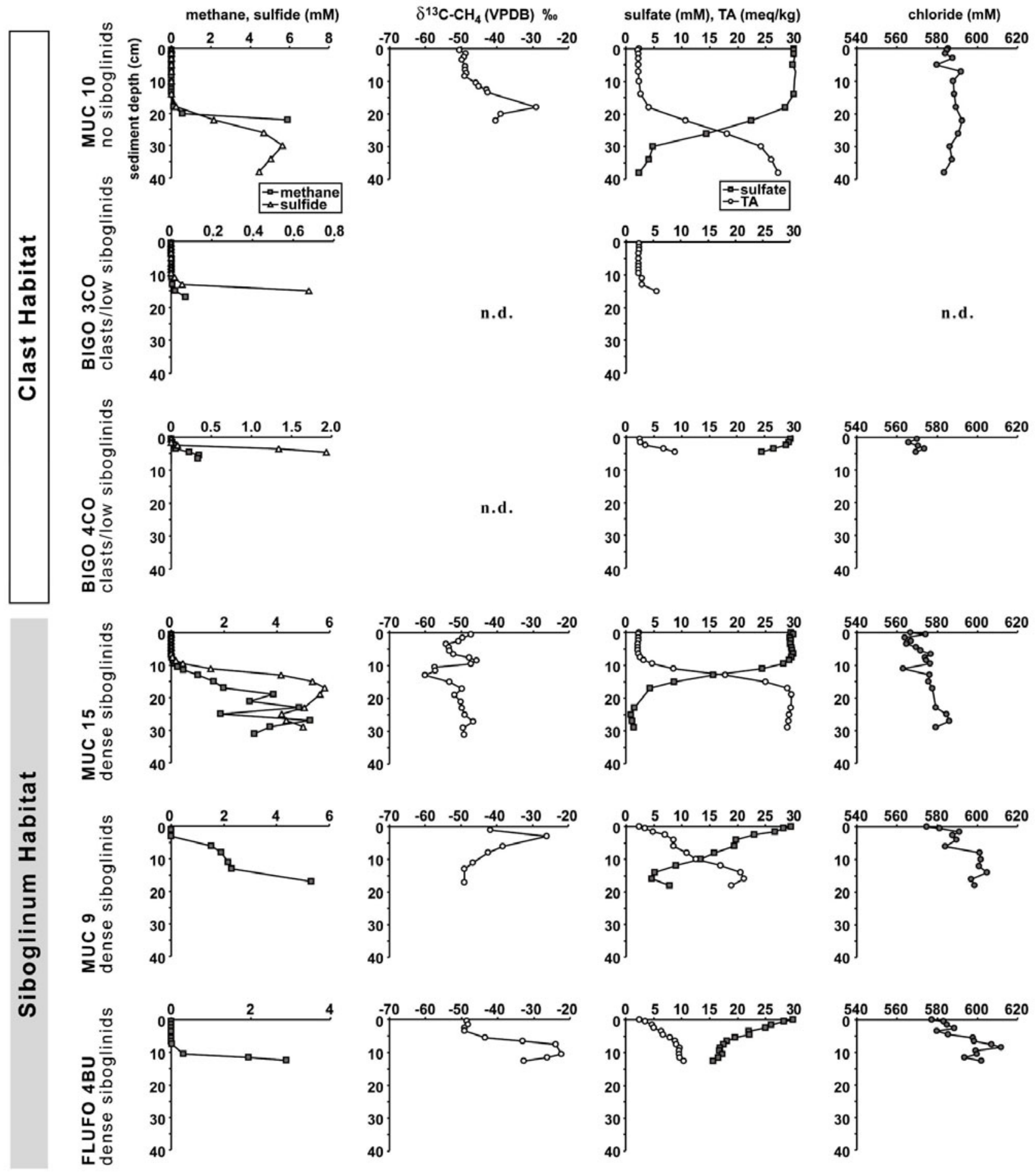

Fig. 8. Pore water concentration profiles of methane, sulfide, $\delta^{13} \mathrm{C}-\mathrm{CH}_{4}$ (VPDB), sulfate, sulfide, total alkalinity and chloride at the investigated sites at the Captain Arutyunov mud volcano 


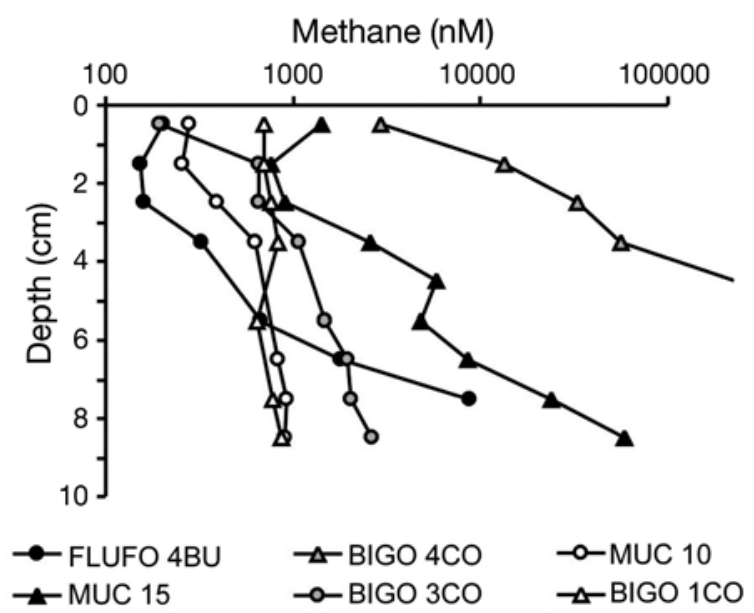

Figure 9: Methane pore water concentration profiles depicted in Fig. 8 for the uppermost $9 \mathrm{~cm}$ of the sediment

to rising gas bubbles. Below this zone the methane was depleted, with ${ }^{13} \mathrm{C}$ displaying an isotope signature of around $-50 \%$.

\section{Sulfate, sulfide, TA, chloride}

Although some sediment cores were very short, the formation or onset of a sulfate-methane reaction zone with an associated increase of dissolved sulfide and TA was discerned at all sites (Fig. 8). Unfortunately, sulfide measurements by FLUFO 4BU and MUC 9 are not available. However, the distinct increase in TA indicates the presence of sulfide in the pore water.

Pore water profiles of methane versus sulfate in the siboglinid habitat displayed very different patterns. At MUC 15, the sulfate concentration did not change in the upper $8 \mathrm{~cm}$; below this depth it decreased sharply. Whereas at MUC 9 and FLUFO 4BU, sulfate decreased almost linearly with depth, implying diffusive sulfate transport to deeper sediment layers, where it is reduced via AOM.

In the clast habitats, the sulfate-methane reaction zone is either located very deep and is therefore outside the maximum penetration depth for some siboglinid tubes (MUC 10, BIGO 3CO), or it is located very close to the surface (BIGO $4 \mathrm{CO}$ ).

At all sites, chloride concentrations were elevated in comparison to the background seawater value (560 mM), indicating input of more saline fluids from below (Fig. 8). At the siboglinid habitat, chloride concentrations above the methane front were lower than those of the deeper sediment horizons. In sediments not colonized with siboglinids (MUC 10), salinity of the pore water did not distinctively change with depth, except for a small chloride minimum at $5 \mathrm{~cm}$ depth.

\section{DISCUSSION}

Small-sized siboglinid tubeworms are a prominent faunal group in the methane and sulfide rich sediments of the CAMV. The genera Siboglinum and Polybrachia belong to the frenulates, which include 5 families and 20 genera (Southward et al. 2005). So far, other areas with almost exclusive dominance of frenulates (as described in this study) have been reported at cold seeps in the central Skagerrak (Flügel \& Langhof 1983), where $S$. poseidoni reaches abundances in the range of 8500 to 18000 ind. $\mathrm{m}^{-2}$ (Dando et al. 2008 and references therein, Callsen-Cencic 1994), and at the Håkon Mosby mud volcano (Oligobrachia haakonmosbiensis, Smirnov 2000, Gebruk et al. 2003). Typically, frenulate tubeworms inhabit muddy sediments on the continental slope, reaching densities of up to 600 ind. $\mathrm{m}^{-2}$ (cf. Dando et al. 2008). However, there are examples of higher densities of siboglinids, e.g. S. fiordicum in organic-rich fjord sediments at densities up to 7000 ind. $\mathrm{m}^{-2}$ (Southward 1979). Presence of small-sized monoliferan tubeworms - similar to frenulates but comprising only 1 genus, Sclerolinum-was reported at hydrothermal vents (Sahling et al. 2005), mud volcanoes in the eastern Mediterranean Sea (Olu-LeRoy et al. 2004) and the Håkon Mosby mud volcano (S. contortum, Smirnov 2000, Gebruk et al. 2003).

In their adult stage siboglinid tubeworms lack a mouth and anus and do not possess a digestive tract. To sustain their metabolism, all species studied so far depend on endosymbiotic sulfide-oxidizing bacteria, which are harbored in the trophosome, located in the posterior part of their body (cf. Southward et al. 2005). Only 1 species, Siboglinum poseidoni, which so far was only found at cold seep sites in the Skagerrak, has been described as relying on methane-oxidizing bacteria (Schmaljohann \& Flügel 1987). Hence we assume that, unlike $S$. poseidoni, the other 2 siboglinids found at the CAMV rely predominantly on endosymbiotic sulfide-oxidizing bacteria.

\section{Siboglinids - a shunt between deep anoxic and oxic surface seep sediments?}

Frenulates depend on simultaneous access to oxygen and sulfide or methane, and have been assumed to have a pronounced effect on methane and sulfur geochemistry due to enhanced advective water and solute transport through their tubes. Callsen-Cencic (1994) observed that steady movements of cilia in the ventral ciliary field, located at the anterior trunk of Siboglinum poseidoni, generate a weak water flow predominantly directed towards the head of the organism, i.e. towards the opening of the tube, which faces toward/into the 
bottom water, although the flow could be reversed. In analogy to the 'gas pipeline' hypothesis by Jensen (1992), Callsen-Cencic speculated that S. poseidoni maintains a suitable methane concentration inside its tube via this water flow to support its endosymbionts, which otherwise would depend on slow passive methane transport via diffusion. From unidentified pogonophoran assemblages at the Håkon Mosby mud volcano, de Beer et al. (2006) assumed enhanced burrow ventilation that allowed sulfate penetration and AOM down to $70 \mathrm{~cm}$ sediment depth. As Håkon Mosby is densely populated by the monoliferan Sclerolinum contortum (Smirnov 2000) and the frenulate Oligobrachia haakonmosbiensis (Smirnov 2000), we assume that de Beer et al. (2006) were referring to O. haakonmosbiensis, which possess a tube length of about 68 $\mathrm{cm}$, with a diameter of $0.83 \mathrm{~mm}$ (Smirnov 2000, Gebruk et al. 2003).

Similar to the observations by de Beer et al. (2006), we also observed a coincidental correlation between the onset of the methane front (correlating with high $\delta^{13} \mathrm{C}-\mathrm{CH}_{4}$ values, indicative of intense AOM) and the depth penetration of the siboglinid tubes. However, due to the morphology of siboglinids, which is not adapted for the regular pumping activity needed for active bioirrigation (E. Southward pers. comm.), observations of their tubes and hydro-mechanical considerations of the water flow, we doubt that siboglinids bioirrigate solutes such as oxygen, nitrate, or sulfate to the sulfate-methane reaction zone.

To our knowledge direct measurements of the bioirrigational activity of siboglinids in their natural environment do not exist. However, onboard in situ observations of siboglinid behaviour revealed that these organisms were rather passive and sporadically showed sluggish gliding movements inside the tube. Laboratory studies of Siboglinum poseidoni, S. fiordicum and $S$. ekmani revealed a similar behaviour (Callsen-Cencic 1994). The inside of the tube was clean, without sediment particles and microbes, which indicates water flow through the tubes (Fig. 7). Moreover, in many small species the anterior end of the tube can be sealed temporarily by secretion of tube material, which prevents exit or entry of water (Southward \& Southward 1963). In addition, we observed that the posterior of the tube can be encrusted, further impeding water exchange. Lastly, caused by the high hydromechanical dampening of the siboglinid tube and the surrounding impermeable muddy sediment, water flow through the tube from the bottom water to deeper sediment horizons or vice versa is, if at all possible, strongly reduced. In such systems molecular diffusion represents the physical process that drives exchange of solutes between water enclosed by the tube and pore water (e.g. Aller 1980, Meysman et al. 2006).
The tube wall of the siboglinids consists of several layers of chitinous/proteinaceous fibre mats similar to plywood and has a restricted permeability to molecules (Gupta \& Little 1975). However, it has been demonstrated that water, solutes and small molecules such as oxygen, butyrate, glucose and phenylalanine diffuse freely across the tube wall of Siboglinum fiordicum (Southward \& Southward 1963, Southward \& Southward 1970, Southward et al. 1986) and it is likely that the tube wall is also permeable for methane and sulfide.

As the sediment surrounding frenulate tubes has been observed to be visibly oxidized (Southward et al. 1986), Dando et al. (2008) suggest that oxygen diffuses from the blood system, across the body and the tube wall into the surrounding sediment. These authors further propose that sulfate resulting from sulfide oxidation of the endosymbionts diffuses back into the sediment. Such release of oxygen and sulfate into the reduced sediment can have pronounced effects on anaerobic methane turnover and cycling of sulfur species (cf. Dando et al. 2008).

In addition to diffusion, we propose a further mechanism for the distribution of solutes inside the tubes. We hypothesize that the ventral ciliary field (VC, Fig. 10) generates a weak circulatory water flow inside the tube but does not facilitate a net transport of water from the deeper sediments to the bottom water or vice versa. This 'stirring of the tube water,' depending on the vertical position of the siboglinid inside the tube and the movement of the animal within the tube, could facilitate the exchange of solutes between the tubeand pore water.

\section{Dense assemblages of extending tubes create a micro-environment above the sediment surface}

Methane emission from the siboglinid habitat was extremely low, primarily due to anaerobic oxidation of methane in the sediment as indicated by the pore water profiles of methane and sulfate. Although the tubes have contact with high pore water methane concentrations, they do not represent ideal escape routes for methane, as slow diffusion appears to be the major transport process across the tube wall, and bioirrigation most likely is negligible. A fraction of the methane that diffuses into the tubes will be consumed by endosymbionts if Siboglinum poseidoni is present. Another fraction might be consumed by methanotrophs attached to the integument of the organisms or the tube wall. However, scanning electron microscopy of the middle section of the tube revealed that neither its outside nor its inside was colonized by bacteria capable of consuming methane. 


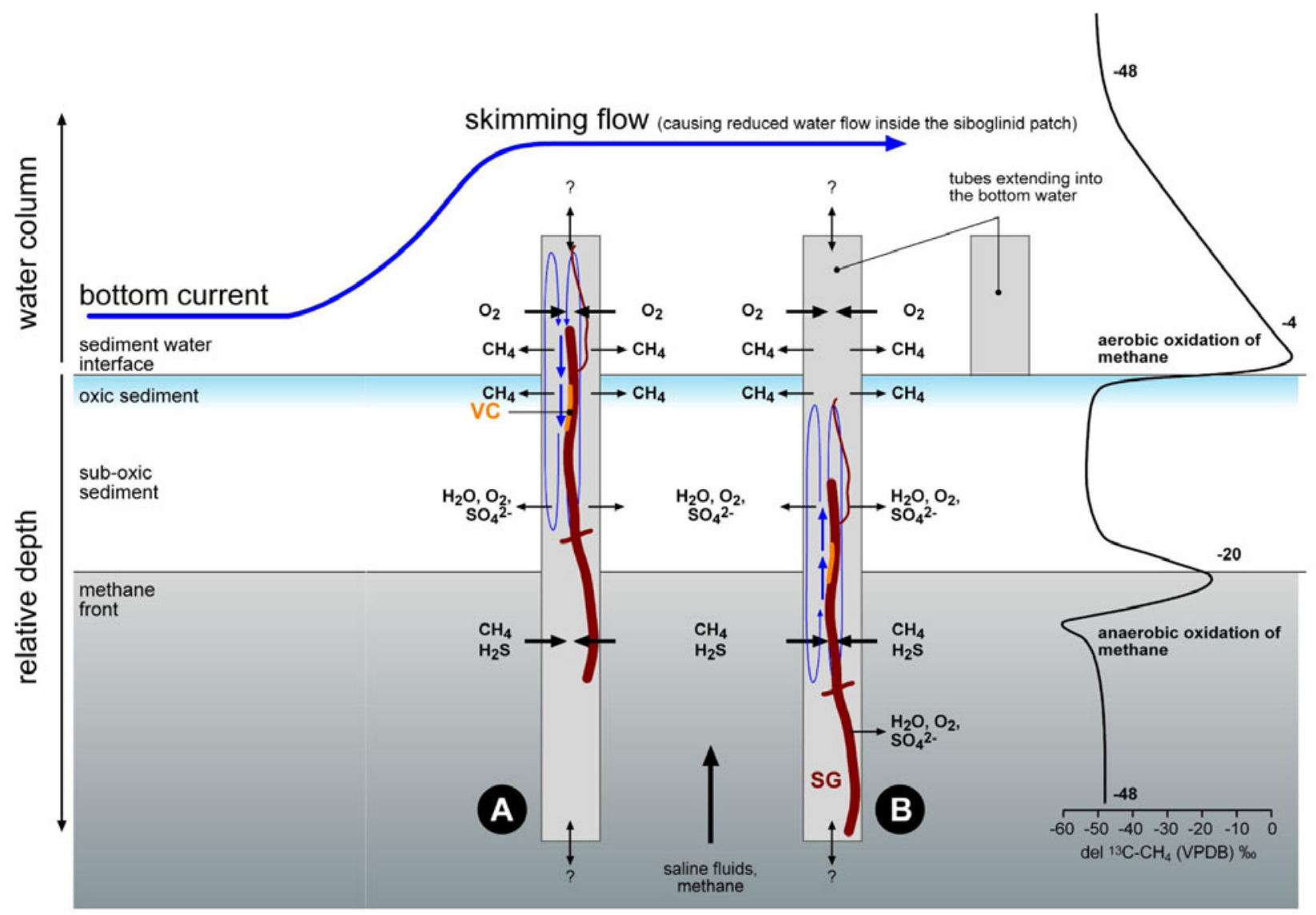

Fig. 10. Conceptual sketch of the siboglinid habitat. The siboglinids (SG) do not bioirrigate bottom water to deeper sediment horizons. Major transport of gases, ions, small sized hydrocarbons and water takes place across the tube via diffusion. A weak circulatory water flow that is generated by the ventral ciliary band (VC) of the siboglinids might assist to overcome slow transport of solutes. Depending on the direction of this circulatory water flow and vertical position of the siboglinid inside the tube (encircled A, B), the organism possibly affects the chemical 'climate' of the tube water. Due to slow diffusion the tubes do not represent ideal escape routes for methane, although a certain fraction of methane entering the tube in deeper sediments likely is released into the oxic bottom water where it can be oxidized aerobically. For detailed explanation and references see 'Discussion'

A proportion of methane that enters the tubes likely diffuses from the tubes into the oxic bottom water, where it can be oxidized aerobically. During deployment of BWS 4 , extremely high $\delta^{13} \mathrm{C}-\mathrm{CH}_{4}$ values of up to $-4.2 \%$ o were measured in the water column a few centimeters above the sediment surface, indicating intense aerobic methane oxidation (cf. Whiticar 1999). Aerobic oxidation of methane is very common in freshwater environments and rates are highest in methane gradients occurring in oxyclines. In the marine environment, strong positive carbon isotope shifts of up to $+49 \%$ were observed at a brine-seawater boundary layer associated with the oxic and anoxic interface in the Red Sea (Schmidt et al. 2003). Furthermore, high rates of aerobic methanotrophy constituting the major pathway of methane oxidation has been documented for the central plain of the methane-emitting Håkon Mosby mud volcano (Niemann et al. 2006). For cold seep sediments at Hydrate Ridge, Sommer et al. (2006) provide indirect evidence for fast aerobic methane consumption rates of 6 to $42 \mu \mathrm{mol} \mathrm{l^{-1 }} \mathrm{h}^{-1}$ in benthic chambers.

Siboglinid tubes create dense forests extending several $\mathrm{cm}$ into the bottom water (cf. Fig. 3C-E). Comparable to terrestrial forests, where wind stress is lowered inside, these tubes create a micro-environment with reduced bottom-water flow, resulting in a vertically extended diffusive benthic boundary layer (cf. Fig. 10). This results in longer residence time of methane for microbial consumption before it is swept away. The effect of polychaete lawns on near-seabed flow dynamics has been demonstrated by Friedrichs et al. (2000), where depending on abundance, spatial arrangement and the length of tubes extending into the water column, the bottom water flow can be strongly decelerated, resulting in a skimming flow above the polychaete lawn. Another effect of such polychaete lawns with reduced flow conditions is that 
particles from the water column are efficiently captured, leading to an overall stabilizing effect of the sediment and thus providing a suitable habitat for diverse microbial communities.

\section{Methane emission from CAMV}

Emission of dissolved methane from the different sites atop CAMV was variable and spanned several orders of magnitudes. Elevated average methane flux was associated with the clast habitat, characterized by low densities or the absence of siboglinids. Methane transport and emission from both predominant habitats at CAMV is driven by diffusion and slow fluid flow velocities in the range of 10 to $15 \mathrm{~cm} \mathrm{yr}^{-1}$ (Hensen et al. 2007).

In comparison to methane fluxes from other seep locations also measured in situ using benthic flux chambers, the methane release from the different sites at CAMV is extremely low. Although the associated biota are very different, the emission rates observed in the clast habitats are similar to those in other seep environments, such as vesicomyid clam beds at Hydrate Ridge, which are characterized by slow fluid flow velocities in the range of 2 to $10 \mathrm{~cm} \mathrm{yr}^{-1}$ and methane emission rates $<1.5 \mathrm{mmol} \mathrm{m}^{-2} \mathrm{~d}^{-1}$ (Torres et al. 2002, Sommer et al. 2006). Both seep ecosystems are further characterized by similar pore water profiles where the methane and sulfide fronts are located deeper (10 to $15 \mathrm{~cm}$ ) in the sediment. As the fluid flow velocity increases, methane emission becomes elevated as well. For mud volcano sediments of Mound 11 off Costa Rica, which are covered with microbial mats and characterized by steep gradients of methane and sulfide close to the sediment surface, Linke et al. (2005) reported a methane flux of $12.1 \mathrm{mmol} \mathrm{m}^{-2} \mathrm{~d}^{-1}$. For the same mound, Wallmann et al. (2006) reported fluid flow velocities in the range of 10 to $300 \mathrm{~cm} \mathrm{yr}^{-1}$. Similarly, Sommer et al. (2006) and Torres et al. (2002) reported in situ methane fluxes in the range of 1.9 to $100 \mathrm{mmol} \mathrm{m}^{-2} \mathrm{~d}^{-1}$, with an associated fluid flow in the range of 1 to $250 \mathrm{~cm} \mathrm{yr}^{-1}$ for microbial mats with underlying gas hydrates at Hydrate Ridge. The low flux rate determined at the siboglinid habitat is unparalleled by any other reported benthic chamber flux measurements in seep locations elsewhere.

Based on the mapping of the 2 distinct seep habitats coinciding with higher methane concentrations in the water column, a total seepage area of $\sim 81421 \mathrm{~m}^{2}$ can be assumed atop CAMV, whereas at the flanks no indications of seepage were discerned. During the video observation a spatial coverage of the clast habitat in relation to the siboglinid habitat of 3.6 was discerned. This ratio, in concert with the respective methane release rates, is assumed to be typical for these 2 habitats and can be used to extrapolate the total emission of dissolved methane to $0.006 \times 10^{6} \mathrm{~mol} \mathrm{yr}^{-1}$ for the CAMV.

This estimate is uncertain, and does not include eruptive events and gas bubbling of methane into the water column. A hydro-acoustic survey of the water column conducted for several days during this cruise revealed only weak gaseous methane emissions from CAMV, which correlates with low methane concentrations in the lower water column. However, methane concentrations of up to $20 \mu \mathrm{M}$ in the bottom water (up to $1 \mathrm{~m}$ above the sea floor) imply that there are sites with localized, probably periodic, enhanced methane release.

During the video inspection of the sea floor we observed furrows (cf. Figs. 3I \& 4) that might be related to sediment instability/erosion and mud flow. At fractures inside these furrows, deeper reduced sediment layers are exposed to the bottom water and could represent sites of enhanced methane release. These furrows were often densely populated by living gastropods, indicating enhanced carbon availability, which might be linked to a methane-carbon and sulfide-sustained chemosynthetic food web. Unfortunately, due to the roughness of the sea floor topography, we were not able to conduct benthic chamber flux measurements at these sites. Moreover, only 1 rate measurement for the siboglinid habitat was obtained, which further introduces uncertainty into our estimate of the overall methane release from CAMV. Lastly, the methane flux rates might represent underestimates, as aerobic methane oxidation in the syringe water samples might have reduced the methane concentration. Methane oxidation in the water column was not measured.

However, even when a maximum methane seabed emission of $0.66 \mathrm{mmol} \mathrm{m}^{-2} \mathrm{~d}^{-1}$, which was observed in the clast habitat (FLUFO 5FLUX), is presumed for the entire seepage area, the annual methane release would increase only 3.3 -fold to $0.02 \times 10^{6} \mathrm{~mol} \mathrm{yr}^{-1}$. This value is still small compared to the overall methane release from other mud volcanoes and mud flows, which range from $0.07 \times 10^{6} \mathrm{~mol} \mathrm{yr}^{-1}$ at Mound 11 off Costa Rica (Mau et al. 2006) to $6.5 \times 10^{6} \mathrm{~mol} \mathrm{yr}^{-1}$ from the Cyclops and Atalante mud volcanoes seaward of the Barbados accretionary prism (Wallmann et al. 2006, their Table 5). Wallmann et al. (2006) argue that high methane emission rates are associated with high rates of water discharge and fluid flow, and extended areas with active mud extrusions where microbial methane consumption is low, as has been observed for the central area of the Håkon Mosby mud volcano (Pimenov et al. 1999). Whereas at mud volcanoes with low emission rates $\left(0.006\right.$ to $0.6 \times 10^{6} \mathrm{~mol} \mathrm{yr}^{-1}$; Captain 
Arutyunov, Kazan, Culebra, Mound 11, Mound 12) methane discharge occurs focused at small, active patches, and diffusive discharge is considered to be negligible since most of the methane is oxidized in the sediment. At CAMV only weak indications of recent mud flows were discerned and methane release appears to be related to the degree of development in the different habitats and establishment of ecosystem functions such as methane and sulfide consumption.

\section{CONCLUSIONS}

Despite the presence of a large subsurface methane reservoir, release of dissolved methane from CAMV is very low compared to other mud volcanoes, both with regard to single benthic chamber flux measurements and with the overall estimate of the entire mud volcano. Such a low methane emission appears to be related to slow fluid flow, which provides time for anaerobic methanotrophic bacteria (microbial filter) to consume a large proportion of the ascending methane, and a wellestablished habitat dominated by siboglinids, which directly and indirectly affects methane turnover.

The present perception of the benthic filter concept is based on the dominance of AOM, which constitutes the major sink for methane in cold seep sediments. On the other hand, the role of seep metazoans has only been poorly defined to date; they are considered to merely benefit from a methane/sulfide-induced chemosynthetic food web. Prominent organisms of the CAMV ecosystem are siboglinid tubeworms, which overcome low fluid flow conditions and benefit from subsurface sulfide and methane reservoirs. In addition to microbial AOM, they potentially contribute to methane-carbon retention in the sediment, either directly by consumption (Siboglinum poseidoni) or indirectly by complex physical interaction with their environment. Their capability to create new mesoscale habitats on the sediment surface by their dense patches of tubes extending out from the sediment into the water column has been neglected in earlier studies. By these means, siboglinids increase habitat heterogeneity and introduce niches for microbial communities, which probably include aerobic and anaerobic methanotrophs.

Acknowledgements. We are grateful for the support of the officers and crew of RV 'MS Merian' during cruise MSM 1/3. Many thanks are due to B. Bannert, M. Pieper, A. Petersen, W. Queisser, and M. Türk for their assistance in deploying the in situ technology. We thank B. Domeyer, K. Krieger and S. Kriwanek for taking care of the biogeochemical analyses on board. We thank K. Stange for the stable isotope analyses of methane carbon. We are grateful to R. Schmaljohann for preparing the SEM images. We are very grateful for the insightful comments and suggestions by E. C. Southward, P. R. Dando and 2 anonymous reviewers, which greatly improved the manuscript. This work was funded by the European Commission's Framework Six programme (HERMES project contract nr. GOCE-CT-2005-511234-1), as well as by the R\&D programme GEOTECHNOLOGIEN funded by the German Ministry of Education and Research (BMBF) and the German Research Council (DFG), COMET project grant 03G0600D. This is publication no. GEOTECH-324.

\section{LITERATURE CITED}

> Aller RC (1980) Quantifying solute distributions in the bioturbated zone of marine sediments by defining an average microenvironment. Geochim Cosmochim Acta 44: 1955-1965

Callsen-Cencic P (1994) Untersuchungen zur Verhaltensökologie, Larvalentwicklung und Neuroanatomie von Siboglinid poseidoni aus dem Skagerrak. PhD thesis, University of Kiel

Cunha MR, Rodrigues CF, dos Santos PR, de Sá CV (2005) The faunal assemblage of the Meknès mud volcano (North African margin off Marocco). Preliminary results of the TTR14 cruise in the Gulf of Cadiz. In: Hamoumi N, Henriet J-P, Kenyon N, Suzyumov AE (eds) Geosphere-biosphere coupling processes: the TTR interdisciplinary approach towards studies of the European and North African margins. Intergovernmental Oceanographic Commission, Report 197 , UNESCO, p 90

Dando PR, Southward AJ, Southward EC, Lamont P, Harvey $\mathrm{R}$ (2008) Interactions between sediment chemistry and frenulate pogonophores (Annelida) in the north-east Atlantic. Deep-Sea Res I 55: 966-996

de Beer D, Sauter E, Niemann H, Kaul N, Foucher JP, Witte U, Schlüter M, Boetius A (2006) In situ fluxes and zonation of microbial activity in surface sediments of the Håkon Mosby Mud Volcano. Limnol Oceanogr 51:1315-1331

Flügel HJ, Langhof I (1983) A new hermaphroditic pogonophore from the Skagerrak. Sarsia 68:131-138

Friedrichs M, Graf G, Springer B (2000) Skimming flow induced over a simulated polychaete tube lawn at low population densities. Mar Ecol Prog Ser 192:219-228

Gardner JM (2001) Mud volcanoes revealed and sampled on the Western Moroccan continental margin. Geophys Res Lett 28:339-342

Gebruk AV, Krylova EM, Lein AY, Vinogradow GM and others (2003) Methane seep community of the Håkon Mosby mud volcano (the Norwegian Sea): composition and trophic aspects. Sarsia 88:394-403

Grasshoff K, Ehrhardt M, Kremmling K (1983) Methods of seawater analysis. Verlag Chemie, Weinheim

Gupta BL, Little C (1975) Ultrastructure, phylogeny and pogonophora. Z Zool Syst Evolutionsforsch Sonderheft 1: 45-63

> Hensen C, Nuzzo M, Hornibrook E, Pinheiro LM, Bock B, Magalhães VH, Brückmann W (2007) Sources of mud volcano fluids in the Gulf of Cadiz-indications for hydrothermal imprint. Geochim Cosmochim Acta 71: 1232-1248

Hilario A, Rodrigues C, Cunha MR (2008) Siboglinidae from the Gulf of Cadiz - an update. Geophys Res Abstr 10: EGU2008-A-12222

Jensen P (1992) Cerianthus vogti Danielsen, 1890 (Anthozoa: Ceriantharia): A species inhabiting an extended tube system deeply buried in deep-sea sediments off Norway. Sarsia 77:75-80 
Jerosch K, Schlüter M, Foucher JP, Allais AG, Klages M, Edy C (2007) Spatial distribution of mudflows, chemotrophic communities, and biogeochemical habitats at Håkon Mosby Mud Volcano. Mar Geol 243:1-17

Judd A, Hovland M (2007) Seabed fluid flow. The impact on geology, biology and the marine environment. Cambridge University Press, Cambridge

Lammers S, Suess E (1994) An improved head-space analysis method for methane in seawater. Mar Chem 47:115-125

> León R, Somoza L, Medialdea T, Maestro A, Díaz-del-Río V, Fernández-Puga MC (2006) Classification of sea-floor features associated with methane seeps along the Gulf of Cádiz continental margin. Deep Sea Res II 53:1464-1481

Levin L (2005) Ecology of cold seep sediments: Interactions of fauna with flow, chemistry and microbes. Oceanogr Mar Biol Ann Rev 43:1-46

Linke P, Wallmann K, Suess E, Hensen C, Rehder G (2005) In situ benthic fluxes from an intermittently active mud volcano at the Costa Rica convergent margin. Earth Planet Sci Lett 235:79-95

> Maestro A, Somoza L, Medialdea T, Talbot CJ, Lowrie A, Vázquez JT, Diaz-del-Rio V (2003) Large scale slope failure involving Triassic and Middle Miocene salt and shale in the Gulf of Cádiz (Atlantic Iberian Margin). Terra Nova 15:380-391

Mau S, Sahling H, Rehder G, Suess E, Linke P, Soeding E (2006) Estimates of methane output from mud extrusions at the erosive convergent margin off Costa Rica. Mar Geol 225:129-144

Meysman FJR, Galaktionov OS, Gribsholt B, Middelburg JJ (2006) Bioirrigation in permeable sediments: Advective pore-water transport induced by burrow ventilation. Limnol Oceanogr 51:142-156

Milkov AV (2000) Worldwide distribution of submarine mud volcanoes and associated gas hydrates. Mar Geol 167: $29-42$

Milkov AV, Sassen R, Apanasovich TV, Dadashev FG (2003) Global gas flux from mudvolcanoes: a significant source of fossil methane in the atmosphere and the ocean. Geophys Res Lett 30(2):1037 doi: 1029/2002GL0165358

> Niemann H, Lösekann T, de Beer D, Elvert $M$ and others (2006) Novel microbial communities of the Haakon Mosby mud volcano and their role as a methane sink. Nature 443:854-858

Olu K, Lance S, Sibuet M, Henry P, Fiala-Médioni A, Dinet A (1997) Cold seep communities as indicators of fluid expulsion patterns through mud volcanoes seaward of the Barbados accretionary prism. Deep Sea Res 44:811-841

Olu-LeRoy K, Sibuet M, Fiala-Médioni A, Gofas S and others (2004) Cold seep communities in the deap eastern Mediterranean Sea: composition, symbiosis and spatial distribution on mud volcanoes. Deep Sea Res I Oceanogr Res Pap 51:1915-1936

Pimenov N, Savvichev A, Rusanov I, Lein A and others (1999) Microbial processes of carbon cycle as the base of food chain of Hakon Mosby Mud Volcano benthic community. Geo-Mar Lett 19:89-96

Pinheiro LM, Ivanov MK, Sautkin A, Akhmanov G and others (2003) Mud volcanism in the Gulf of Cádiz: results from TTR-10 cruise. Mar Geol 195:131-151

Reeburgh WS (2007) Oceanic methane biogeochemistry. Chem Rev 107:486-513

Rehder G, Keir RS, Suess E, Rhein M (1999) Methane in the northern Atlantic controlled by microbial oxidation and atmospheric history. Geophys Res Lett 26:587-590

Rodrigues CF, Cunha MR (2005) Common chemosynthetic species in the Gulf of Cadiz: Updated spatial distribution.
In: Hamoumi N, Henriet J-P, Kenyon N, Suzyumov AE (eds) Geosphere-biosphere coupling processes: the TTR interdisciplinary approach towards studies of the European and North African margins. Intergvoernmental Oceanographic Commission, Report 197, UNESCO, p 90

Sahling $\mathrm{H}$, Wallmann $\mathrm{K}$, Dählmann A, Schmaljohann R, Petersen S (2005) The physicochemical habitat of Sclerolinum sp. at Hook Ridge hydrothermal vent, Bransfield Strait, Antarctica. Limnol Oceanogr 50:598-606

Sauter EJ, Muyakshin SI, Charlou JL, Schlüter M and others (2006) Methane discharge from a deep-sea submarine mud volcano into the upper water column by gas hydratecoated methane bubbles. Earth Planet Sci Lett 243: 354-365

Schmaljohann R, Flügel HJ (1987) Methane-oxidising bacteria in Pogonophora. Sarsia 72:91-98

Schmidt M, Botz R, Faber E, Schmitt M, Poggenburg J, Garbe-Schönberg D, Stoffers P (2003) High-resolution methane profiles across anoxic brine-seawater boundaries in the Atlantis-II, Discovery and Kebrit Deeps (Red Sea). Chem Geol 200:359-375

Smirnov RV (2000) Two new species of Pogonophora from the arctic mud volcano off northwestern Norway. Sarsia 85: $141-150$

Sommer S, Pfannkuche O, Linke P, Luff R and others (2006) Efficiency of the benthic filter: biological control of the emission of dissolved methane from sediments containing shallow gas hydrates at Hydrate Ridge. Global Biogeochem Cycles 20. doi:10.1029/2004GB002389

Sommer S, Türk M, Kriwanek S, Pfannkuche O (2008) Gas exchange system for extended in situ benthic chamber flux measurements under controlled oxygen conditions: first application - sea bed methane emission measurements at Captain Arutyunov mud volcano. Limnol Oceanogr Methods 6:23-33

Somoza L, Diaz-del-Rio V, León R, Ivanov M and others (2003) Seabed morphology and hydrocarbon seepage in the Gulf of Cadiz mud volcano area: acoustic imagery, multibeam and ultra-high resolution seismic data. Sedimentary processes and seafloor hydrocarbon emission on deep European continental margins. Mar Geol 195:153-176

Southward EC (1979) Horizontal and vertical distribution of Pogonophora in the Atlantic Ocean. Sarsia 64:51-55

Southward AJ, Southward EC (1963) Notes on the biology of some pogonophores. J Mar Biol Assoc UK 43:57-64

Southward AJ, Southward EC (1970) Observations on the role of dissolved organic compounds in the nutrition of benthic invertebrates. Experiments on three species of pogonophora. Sarsia 45:69-96

Southward AJ, Southward EC, Dando PR, Barrett RL, Ling R (1986) Chemoautotrophic function of bacterial symbionts in small Pogonophora. J Mar Biol Assoc UK 66:415-453

Southward EC, Schulze A, Gardiner SL (2005) Pogonophora (Annelida): form and function. Hydrobiologia 535-536: 227-251

Torres ME, McManus J, Hammond DE, de Angelis MA and others (2002) Fluid and chemical fluxes in and out of sediments hosting methane hydrate deposits on Hydrate Ridge, OR, I: Hydrological provinces. Earth Planet Sci Lett 201:525-540

Wallmann K, Drews M, Aloisi G, Bohrmann G (2006) Methane discharge into the Black Sea and the global ocean via fluid flow through submarine mud volcanoes. Earth Planet Sci Lett 248:544-560

Whiticar MJ (1999) Carbon and hydrogen isotope systematics of bacterial formation and oxidation of methane. Chem Geol 161:291-314 